\title{
Developing Internationally Uniform Liability Principles for Harms from Genetically Modified Organisms \\ by
}

\section{Ryan Hansen}

\author{
Introduction
}

\begin{abstract}
At the dawn of the $21^{\text {st }}$ Century, the existing world order is under attack. As the War on Terrorism attempts to dismantle violent threats to world stability, massive protests continue against the World Trade Organization (WTO) and other instruments of global economic integration. The expansive international media coverage of such events has focused the world's attention on the widening global gap between rich and poor, and the increasingly desperate measures employed by those who seek to alter the status quo. Whether one talks of "globalization" or "interdependence," it is clear that rising voices for change have prompted a re-examination of the current policies and organizational structures used to promote and regulate international trade and sustainable development. ${ }^{1}$ Given the enormous scope of the current fight to reshape the economic world order, it is an interesting paradox that one of its most important battles is taking place at the molecular level over the role to be played by genetically modified organisms (GMOs).
\end{abstract}


Uncertainties regarding the implications of GMO use have engendered controversy in many spheres - political, ethical, scientific, environmental and economic. Questions persist regarding the benefits and risks of the technology and the correct regulatory approaches to address them. The uncertainty of liability for harms flowing from the use of GMOs in agriculture has contributed to stringent regulation, trade barriers, massive lawsuits, and the rejection of desperately needed food aid. ${ }^{2}$ Clearly, the societal costs of such uncertainty are high.

By clarifying the legal standards and reasoning applicable to various GMO disputes, the legal profession can facilitate better decision making by the relevant actors, thereby lowering societal costs. This task is best accomplished by examining the considerations motivating participants in the GMO controversy and the impact of those considerations on current GMO policies. Thereafter, the legal profession can further define the role of GMOs in the existing legal structure or fashion new approaches to meet the novel challenges presented by the technology. GMOs present liability issues in a wide range of contexts. Risks to consumers, the environment, and various economic interests all must be accounted for, with each type of risk posing distinct liability issues that require 
solutions tailored to the relevant situation. This paper seeks to contribute to the process of developing liability principles applicable to disputes involving GM plant varieties by giving an overview of the technology and relevant issues (part I) as well as current international approaches to GMO regulation and liability (part II). It concludes by recommending liability standards applicable to various harms, as well as possible international frameworks to facilitate the implementation of those standards (part III) .

\section{Part I}

GMO Technology and Relevant Issues

Among the many players in the globalization drama, perhaps none plays a more crucial role than agriculture. Lacking large numbers of highly skilled workers or widespread access to capital, the economies of many developing countries depend heavily on agricultural trade. ${ }^{3}$ As such, the optimal functioning of an international market in agricultural related products is crucial to meeting the development goals of these nations. ${ }^{4}$ Yet developing countries seeking progress via increased markets for their agricultural exports face substantial obstacles. Large 
government agricultural subsidies in developed countries, widespread drought accompanying global climate change, expanding intellectual property protections for plant varieties controlled by corporate interests- these are just some of the factors which threaten the viability of sustainable agricultural economies in the developing world. ${ }^{5}$ Yet no issue appears as divisive or as uncertain as the role GMOs will play in shaping the outcome of the emerging international trade and development structure. Some background history of the technology and the debate can help cut through the fierce rhetoric currently employed by both sides.

A. GMO Technology

The technology employed to produce GMOs belongs to the field known as "biotechnology." The United Nations has defined biotechnology to mean "any technological application that uses biological systems, living organisms, or derivatives thereof, to make or modify products or processes for specific use." ${ }^{6}$ Despite the more recent coining of the term, the underlying technology itself has been around for ages without creating catastrophic consequences or any notable regulatory difficulties. Farmers and biologists 
have been crossbreeding selected traits in plants and animals for ages, usually within a single species or species complex. ${ }^{7}$

Many of the most common foods we eat today were initially derived through the application of selective breeding technology. For example, Brussels sprouts, cabbage, broccoli and cauliflower all were selectively bred from the wild mustard seed. ${ }^{8}$ Yet the technology behind the process of selective genetic breeding has advanced to the point where it is now possible to combine desirable traits of two parent organisms into a single offspring without either of the parents belonging to closely related species. ${ }^{9}$ For instance, instead of crossbreeding two types of soybeans to transfer desired properties into the resulting hybrid seed, scientists today can identify desired traits in the DNA of organisms far removed from soybeans, and insert those traits directly into the genetic makeup of the new seed.

The results of genetic engineering can be as intriguing as a tobacco plant with glowing leaves, created by crossing firefly genes with the genes of a tobacco plant. ${ }^{10}$ The addition of genes from vastly different organisms is accomplished through the use of recombinant DNA technology. ${ }^{11}$ The resulting organism is referred to as 
either a GMO, an LMO (for Living Modified Organism), or as a "transgenic" product. ${ }^{12}$

In recent years the proliferation of transgenic crops has been dramatic. From 1996 to 2002, the global area of transgenic crops increased more than 35-fold. ${ }^{13}$ The greatest GMO planting has been in soybeans, corn, canola and cotton. ${ }^{14}$ Today, GMOs comprise over $21 \%$ of world planting in these four principal crops, accounting for farming in excess of 58 million hectares, an area approximately two and a half times the size of the United Kingdom. ${ }^{15}$ While GMO planting appears to have reached a plateau in industrialized countries, the rate of adoption of GMO crops in developing countries has steadily increased ${ }^{16}$. The increased use of GMO crops in developing countries is not surprising, given the history of the technology.

Widespread research into the promises of selective genetic engineering developed strongly during the 1970's, partly in response to concern that accelerating world population growth would soon outstrip sustainable world food production levels. Fear of the resulting mass starvation prompted increased scientific inquiry into technological breakthroughs capable of improving global food productivity and genetic diversity. ${ }^{17}$ In recent decades, however, the efficiencies in agricultural production reached in part from 
technological advances such as GMOs have led many to conclude that the biggest problem for those facing starvation is not the insufficiency of the world food supply, but poverty. It is abject poverty stemming from a host of political, economic, and environmental problems that denies people sufficient access to food. ${ }^{18}$ This revelation is important in the GMO context because as the benefits and risks of the technology are debated, an important question to address is the effect GMOs will have on poverty in the very developing nations whose starvation concerns ignited the initial forays into the technology. The assessment of the role of GMOs in either exacerbating or alleviating poverty in the developing world will play a large part in determining the appropriate policies regarding risk assessment procedures as well as the allocation of liability in GMO disputes.

Compounding the task of developing appropriate policies regarding GMOs is the fact that there currently exists considerable disagreement regarding their benefits and risks. ${ }^{19}$ Both opponents and supporters of GMOs have divergent views on what expanding use of the technology will mean for human health, the environment, and the global economy. What follows is a summary of some of the most 
pervasive arguments for and against the use of GMOs in these contexts.

B. Human Health Implications

Supporters of GMOs tout the many potential benefits of the technology for human health, including increased nutritional values of foods and the development of biopharmaceuticals. While current GMO crops have largely resulted in benefits for seed companies and farmers, "second generation" GMO crops promise to offer consumers added nutritional benefits. ${ }^{20}$ These benefits include products with more vitamins and minerals, greater cancer fighting properties, less fatty acids, and reduced toxins and allergens. ${ }^{21}$

A widely publicized GMO containing added nutritional benefits is "golden rice." Golden rice is rice genetically enhanced to contain added iron and beta-carotene, the precursor to vitamin A, to help prevent blindness and improve the effectiveness of immune systems. ${ }^{22}$ Such products are vital to alleviating malnutrition in the developing world, where close to 800 million people are undernourished. ${ }^{23}$ 
Genetic modification of plants to add pharmaceutical properties offers incredible potential to lower the cost of treatment for many ailments. For instance, researchers are working to build a vaccine for hepatitis B into bananas. This reduces the dosage cost from $\$ 125$ to 2 cents, while avoiding the costs of refrigeration and administration by medical personnel. ${ }^{24}$ Instead of taking vast amounts of pills, people can conceivably get their needed vaccines and medications simply by eating doctor approved "pharmafoods". ${ }^{25}$

In addition to the seemingly limitless potential human health benefits, supporters point out that no scientific evidence currently exists that demonstrates current GM foods pose health risks. ${ }^{26}$ Producers of GMOs know exactly what genetic traits they are inserting into their products, while products produced through traditional "wide cross" breeding methods can not selectively screen out undesired traits. ${ }^{27}$ GM products also undergo extensive pre-market testing for toxicity and allergen properties that traditional products are not forced to comply with, all of which may render GM foods safer than their traditional and organic counterparts. ${ }^{28}$

While current GM foods have not been shown to have adverse effects, that fact is of little comfort to opponents 
of GMOs who argue that because GM foods have only recently come to market, their long-term effects have yet to be studied. ${ }^{29}$ The addition of novel genes to familiar foods presents many with a recipe for disaster. ${ }^{30}$ According to a Greenpeace GMO opponent, dangerous unforeseen consequences from genetic modification are extremely likely. "Because no gene ever functions in isolation, there will almost always be unexpected and unintended 'side effects' from the gene or genes transferred into an organism." ${ }^{31}$

The demonstrated health risks of GMOs include the possibility of allergic reactions. In late 2000 - early 2001 hundreds of different food products were recalled because they contained a GM corn that the FDA had not approved for human consumption, citing concerns over possible allergic reactions. ${ }^{32}$ The lack of effective quarantine procedures to isolate GMO grain from traditional grain at many levels of the production and distribution lines means future contamination scares are a very real possibility. ${ }^{33}$ Commingling, mishandling, and genetic drift all pose obstacles to efforts to isolate GMOs from traditional crops in the food supply. ${ }^{34}$ Along with the danger of allergic reaction is the possibility that the widespread use of antibiotic resistance marker genes ${ }^{35}$ in GM crops could increase the antibiotic resistance of human 
pathogens. ${ }^{36}$ This would render many essential antibodies ineffective, hampering the ability of doctors to control disease outbreaks. ${ }^{37}$

B. Implications for the Environment

Proponents of GMOs argue that the widespread use of transgenic crops will benefit the environment in multiple ways. GMO products will allow for the dissemination of a smaller amount of hazardous materials into the environment while simultaneously demanding less of the limited natural resources needed to grow crops. ${ }^{38}$ By creating crops with built in insect or herbicide resistance, GM crop producers can decrease the amount of toxic chemicals farmers must constantly apply to their fields. ${ }^{39}$ GMOs used as animal feed can be created to reduce the amount of harmful pollutants like phosphorous that are passed from animals into the environment ${ }^{40}$. Because yields will increase due to fewer pests and more uniform, robust crops, less land needs to be converted to agricultural use, leaving existing ecosystems undisturbed. ${ }^{41}$ Higher yields and less cropland also translate into reduced tilling and water use, minimizing soil erosion and easing demands on limited fresh water supplies. ${ }^{42}$ 
Scientists are also exploring ways to use GMOs in environmental remediation and conservation. By using GMOs bio-engineered to absorb metals or detoxify hazardous substances, environmental cleanups can be done in a more ecologically friendly manner. ${ }^{43}$ It is also possible to use GMOs as biosensors to act as warning systems to the presence of hazardous materials. ${ }^{44}$ GMOs can assist in the recovery of endangered species as well as species that have been devastated by exotic pests. ${ }^{45}$ It may even be possible through cloning procedures to reintroduce extinct species into their native habitat. ${ }^{46}$ In such ways GMOs could contribute to a valuable increase in genetic diversity. Where GMO proponents see the technology as holding promising environmental benefits, critics see cause for serious concern, and express doubts about the validity of pro-GMO claims. GMO critics argue that alongside the potential to bring about dangerous unintended consequences in the organisms being genetically engineered is the risk that GMOs will provoke damaging unintended effects on surrounding ecosystems. Ecosystems survive on a delicate balance of complex factors. This balance can be easily disrupted by the presence of foreign species or redistribution amongst symbiotic species. ${ }^{47}$ GMOs may contribute to disrupting the balance of ecosystems through 
gene flow, displacement of other species, loss of genetic diversity and associated environmental damage. ${ }^{48}$

Gene flow describes the transfer of genes to other organisms and is seen as a sizeable risk of GM crops. ${ }^{49}$ Gene flow is greatest between crops and neighboring wild relatives but can also occur "horizontally" through transfers to bacteria in the soil or to animals that eat the crops. ${ }^{50}$ One danger is that gene flow from GMOs to wild species will confer a "fitness advantage" on certain plants, placing other species in the ecosystem at risk of being squeezed out in favor of the stronger plant, thereby disrupting the balance of the ecosystem. ${ }^{51}$ A particularly disquieting prospect is the thought of "superweeds" that have acquired the herbicide resistance of their GMO neighbors. ${ }^{52}$ Such pests would work to counteract the supposed productivity gains of GMOs and may result in the need for weed control methods that are even more toxic than current spraying practices. ${ }^{53}$ GMOs bred to contain insecticides, such as Bt corn, could prompt insects to mutate into "superbugs" necessitating the use of more environmentally hazardous pesticides. ${ }^{54}$ Toxins produced by insect-resistant crops could potentially harm non-target beneficial insects that are natural pest predators. ${ }^{55}$ The 
overall effect could be an increase in the pest population and a decline in insect genetic diversity. ${ }^{56}$ While seed companies and government agencies like the EPA can require GMO planters to institute programs aimed at mitigating these effects, no program will be able to eliminate the dangers entirely ${ }^{57}$

Another environmental danger commonly linked to GMOs is that large-scale cultivation of GM crops could bring about a decrease in genetic diversity. Because of the considerable expense involved in bringing a GMO to market, companies are likely to develop only varieties they foresee as profitable. Currently, farmers in the developed world constitute the biggest market for GMOs, and the bulk of their trade occurs in a small number of crops such as corn and soybeans - crops not favored by farmers in many parts of the developing world. ${ }^{58}$ If farmers in developing countries switch to GM varieties over traditional local crops in an attempt to achieve greater production efficiencies, important crop varieties in those countries could become scarce or nonexistent. If GMOs transfer their increased "fitness" genes (better resistance to insects, etc.) to wild relatives, essential varieties of species could be lost. ${ }^{59}$ The resulting homogenization of cropland could mean a decreased pool of genetic resources from which to extract 
valuable medical cures or other important biological applications. ${ }^{60}$ This is of course in addition to the attendant losses to cultural and national heritage, as well as scenic beauty. ${ }^{61}$ Society's decision to trade losses in these areas for potential gains from GMOs is complicated by the lack of an objectively quantifiable method or scale on which to effectively assess competing values. ${ }^{62}$

\section{Economic Implications}

While the persuasiveness of arguments concerning the health and environmental impacts of GMOs are handicapped on both sides of the debate by a lack of scientific certainty, that disability is lessened when discussing the economic implications of the technology. While the enormous potential economic repercussions of GMOs leave much room for argument $^{63}$, many specific financial gains and losses arising from the technology have already been identified.

For supporters of GMOs the economic argument is simple. GM products help farmers expand production yields at lower costs. These production savings can than be passed along to consumers as cost savings. ${ }^{64}$ Recent studies have placed the savings to US growers of 8 existing GM crops at $\$ 1.2$ billion, coupled with an increase in yields of 4 billion 
pounds and a decrease in pesticide use of 46 million

pounds. ${ }^{65}$ If approval were secured for 32 other varieties currently in the testing stages, the net value to U.S. agriculture alone would exceed $\$ 2.5$ billion in increased yields and cost savings. ${ }^{66}$ The U.S. experience in reducing costs and increasing yields with GM crops could be transferred to developing countries to play an important role in reducing poverty. A recent study of GM crop farmers in South Africa saw them experience significant yield gains and chemical cost savings. In addition, the resulting decreased pesticide use allowed the farmers to reduce labor costs while realizing associated environmental and health benefits. ${ }^{67}$ These gains were strongest among the smallest producers, even with the increased cost of GM seeds, illuminating a point pressed by GM supporters that it is the poor in the developing world who stand to gain the most from the switch to GM crops. ${ }^{68}$

In spite of these claims, the link between decreased production costs and lower prices that is stressed by supporters of GMOs in the U.S. biotech and farm industries has been disputed by some who feel that investments in more traditional agricultural production improvements would increase yields at lower costs and without the risks posed by biotechnology. ${ }^{69}$ In any event, promises of economic 
benefits have not been enough to overcome consumer fears regarding the safety of the products elsewhere in the world. ${ }^{70}$ While U.S. consumers have adopted GMO products without serious resistance, throughout Europe and elsewhere consumer, environmental, and trade groups opposed to GMOs have proved successful in mobilizing campaigns directed at persuading government authorities to establish strict regulatory requirements for GMOs. ${ }^{71}$ Authorities have responded to these concerns with mandatory labeling requirements, moratoriums on approval of GM products, even outright prohibition of GMOs. ${ }^{72}$

The result of these negative reactions to GMOs has been to set up costly barriers to farmers and biotech industry players intent on penetrating these markets with their GM products. U.S. agricultural export losses due to stringent regulation of GMOs abroad have been high, provoking talk of the U.S. bringing WTO dispute proceedings against the E.U. over their ban on genetically modified food. ${ }^{73}$ Export losses to the E.U. alone are estimated to cost U.S. companies over $\$ 4$ billion dollars per year. ${ }^{74}$ In addition, some of the larger U.S. food processors, such as Archer Daniels Midland $(\mathrm{ADM})$, have announced intentions to reject genetically modified crops that are not accepted in the European market. ${ }^{75}$ Prominent food producers around the world have 
also instituted similar GMO-free policies in order to ensure they are not denied access in the global food market. ${ }^{76}$

While economic losses resulting from a lack of market access for GM crops abroad are based on estimations of sales lost, many organic and non-GMO farmers have experienced financial losses from GMOs of a more local, particularized nature. Buyers in Europe and elsewhere with customers fearful of the presence of GMOs often contract with farmers to purchase harvests of their crops that have been certified GMO-free. ${ }^{77}$ While these contracts can carry prices up to two times the standard commodity price for the crops, the contracts are very strict in their GMO-free requirements, usually enabling the buyer to terminate the contract if testers find the crop to be contaminated with GM seed. ${ }^{78}$ Owing to the ease with which GM seeds can contaminate non-GM fields and grain stores, ${ }^{79}$ maintaining crop purity has been a losing battle for many farmers. ${ }^{80}$ Farmers are often devastated as anticipated profits from their costly efforts at maintaining non-GM status quickly vanish when crop testings reveal their harvests to contain even a fraction of GM protein. ${ }^{81}$

Both Canada and the U.S. have reacted to the special purity concerns of organic farmers by adopting certification programs to protect the valuable organic market. ${ }^{82}$ However, 
these programs are of little use to farmers wishing to sell their crops outside North American. Farmers outraged over the current situation have initiated widespread class-action lawsuits targeting GM developers like Monsanto, Syngenta and Pioneer Hi-Bred. ${ }^{83}$ Attempts to make biotech giants such as Monsanto liable for damage caused by their seeds have encountered many obstacles, not the least of which are the well financed legal defense teams employed by the biotech companies. ${ }^{84}$

Farmers who wish to grow GM crops can't purchase the seeds outright. Growers must purchase a license (usually called a "technology use agreement") containing strict growing guidelines and conditions in addition to disclaimers and limited warranties, all designed to limit the biotech company's liability. ${ }^{85}$ Undaunted, current lawsuits will test the boundaries of current statutory and common law liability for GMO harm in the U.S. and Canada. The success or failure of their efforts will likely play a large role in shaping the debate on whether existing legal standards and remedies are capable of adequately balancing societal goals with the needs of parties to a GMO dispute.

While most lawsuits to date have attempted to get at the bigger pockets of GM seed companies rather than GM farmers, GM farmers are not immune from liability for GMO 
harm. Lacking clear liability standards regarding GMOs and faced with biotech developers' attempts to contract away liability, farmers are looking to the insurance industry for protection. Yet the insurance industry has been slow to warm to the prospect of insuring against GMO harms. Without clear indications regarding the full extent of liability facing policyholders, insurance companies have had difficulty making the risk evaluations necessary to offer appropriate coverage. ${ }^{86}$ While companies are beginning to offer insurance policies for both farmers and biotech companies potentially liable for damage from GMOs, current legal uncertainties ensure the existence of gaps in policy coverage and higher policy costs. ${ }^{87}$ Without clear legal liability standards, the long-term viability of GMO based policies is difficult to predict. At present it is safe to say that regardless of whether or not GM crops bring about cost savings, potential liability for GMO harms, including measures to reduce that liability, represent cost increases attributable to GM crops. ${ }^{88}$

Part II

International Rules and Standards Applicable to GMOs 
Effective rules on responsibility and liability function so as to encourage prevention as well as restoration or compensation. ${ }^{89}$ The enactment of objective standards regarding acceptable conduct enables decisionmakers to make risk/reward choices on a more informed basis. By delineating procedural and substantive norms applicable in various GMO contexts, authorities give shape to standards of liability controlling on parties to a GMO dispute. It is therefore important to understand the regulatory procedures of governments and other authoritative bodies, compliance with which may serve as an objective indication of acceptable behavior.

GMOs are subject to national and international regulation regarding human health and environmental safety, trade, and intellectual property rights. Rules and regulations bearing on liability govern GMOs throughout their product cycle. Currently, most biotechnology regulation takes place at the domestic level. ${ }^{90}$ The divergent approaches taken in the U.S. and E.U. to the regulation of GMOs are indicative of the lack of international consensus on the proper way to deal with the challenges and uncertainties of the new technology. 
A. GMO Policy in the United States

Although the United States may have begun its life as a European colony, the two cultures have developed different attitudes towards acceptance of new technologies, especially those with impacts on food. ${ }^{91}$ Europeans have been more skeptical of new technologies and have tended to favor traditional foods seen as more closely associated with the land. In contrast, Americans are generally more accepting of innovative new technologies promising benefits for business and society. ${ }^{92}$ Whereas GMOs met with distrust upon their appearance in the European market, in America they were greeted with a presumption of safety. ${ }^{93}$

The different approaches to food and new technology in the E.U. and the U.S. have led to divergent regulatory regimes. In the U.S., the focus is on the GMO product alone, while the E.U. approaches the GM process itself as one requiring added scrutiny. In order to preserve public and industry trust in the regulatory process, the U.S. believes that regulatory decisions should be transparent, predictable, and based on sound scientific evidence. ${ }^{94}$ The regulatory framework of biotechnology in the U.S. is driven by the principle that the final product must be safe. ${ }^{95}$ It is this product-focused approach that is the hallmark of the 
American system. ${ }^{96}$ Illustrative of the distinction between the product-based U.S. regulatory focus and a process-based approach is a statement by the FDA in 1992 regarding biotechnology food regulation. "The regulatory status of a food, irrespective of the method by which it is developed, is dependent upon objective characteristics of the food and the intended use of the food (or its components)." ${ }^{97}$ The idea is that products possessing similar characteristics, whether transgenic or conventional, should have their risks assessed on an equal basis. The principle is one of "substantial equivalence" and is the majority view within the scientific community. ${ }^{98}$

The U.S. has not enacted regulatory measures specifically focused on concerns about GMOs. It has instead chosen to regulate GMOs pursuant to their intended use by utilizing the capacities of existing federal agencies. ${ }^{99}$ This structure was set down in 1986 when the office of Science and Technology issued the Coordinated Framework for Regulation of Biotechnology. ${ }^{100}$ The Framework divides the regulation of GMOs among three executive agencies: the United States Department of Agriculture establishes whether GMOs are 'safe to grow'; the Environmental Protection Agency decides if GMOs are 'safe for the environment'; and the Food 
and Drug Administration (FDA) determines whether GMOs are 'safe to eat'. 101

In regulating GM plants, the USDA acts through the Animal and Plant Health Inspection Service (APHIS) pursuant to congressional authority under the Plant Protection Act of 2000.102 APHIS regulates the movement, importation, and field testing of GMOs via permits and notification procedures. ${ }^{103}$ Before a biotech crop can be field tested, a permit must first be secured from APHIS. Most often this is done via a streamlined procedure whereby an applicant must notify APHIS prior to moving or field testing a crop. The applicant must provide all relevant information about the crop, including likely adverse impacts on the environment, target, and non-target species. ${ }^{104}$ Before the GMO can be brought to market, the applicant must submit a petition to APHIS showing that field trials have shown the plant to be safe. ${ }^{105}$ If the plant qualifies as safe, APHIS issues a "determination of non-regulated status", meaning the plant will be treated like any other plant and can be widely grown and commercialized. ${ }^{106}$ All GMO petitions are published in the Federal Register, and the public is given time to comment. ${ }^{107}$ The EPA derives its regulatory authority over GMOs from 3 primary sources: the Toxic Substances Control Act 
$(\mathrm{TSCA})^{108}$; the Federal Insecticide, Fungicide, and

Rodenticide Act (FIFRA) ${ }^{109}$; and the Federal Food, Drug and Cosmetic Act (FFDCA). ${ }^{110}$ TSCA gives the EPA the authority to determine if chemical substances (including microorganisms) present an unreasonable risk to health and the environment. ${ }^{111}$ Under FIFRA, the EPA evaluates GM crops engineered to contain pesticidal properties (such as Bt corn), and requires companies to register and label their GMOs as pesticides. ${ }^{112}$ FIFRA also requires companies to gather data on the environmental effects of the GMO, including its overall pesticide effectiveness, to ensure that no 'unreasonable adverse effects on the environment' occur. ${ }^{113}$ Current EPA regulations require farmers of GM crops like Bt corn to devote a percentage of their crop land to non-GMO varieties to slow pest resistance. The regulations also encourage farmers to plant non-GMO varieties around the edge of their GMO crops in order to create a "buffer zone" to protect neighboring fields and habitats. ${ }^{114}$

If a GM plant contains pesticide chemicals and is destined for human consumption, the EPA will regulate it under FFDCA. The FFDCA requires that the EPA establish maximum tolerance levels to ensure that "no harm will result from all anticipated dietary and other exposures."115 Most 
GMOs have been exempted from tolerance requirements after extensive safety testing showed public health would not be endangered by their consumption. ${ }^{116}$

The FDA uses the FFDCA as its primary regulatory authority over the safety of GM foods. The FFDCA contains provisions governing food additives and adulteration of foods. ${ }^{117}$ In addition, the FFDCA places a legal obligation on companies to ensure that any food they sell meets existing safety standards. ${ }^{118}$ In the past, companies wishing to place GM food on the market engaged in a voluntary consultation process with the FDA to help determine if their product met current legal safety standards. ${ }^{119}$ In consultations, companies provided the FDA with data summarizing the modifications they had made to their product and why it was as safe as conventional food. ${ }^{120}$ In January of 2001 the FDA responded to consumer concerns by proposing that such consultations be required of all genetically engineered foods. ${ }^{121}$ The new procedure requires companies to notify the FDA at least 120 days before their products are marketed by submitting a Pre-Market Biotechnology Notice (PBN) containing the same type of data and product information previously exchanged during consultations. ${ }^{122}$ Both the initial PBN as well as the FDA response are accessible to 
the public via the internet. ${ }^{123}$ The proposal is noteworthy in that it still does not require the FDA to either approve a GMO before it comes to market or to conduct independent tests to determine GMO safety. Because the FDA views GM foods as sufficiently similar to conventional foods, and therefore "generally recognized as safe," no pre-market independent testing or approval is required. The FFDCA uses the prospect of criminal liability for introducing an unsafe product into the market as assurance that companies will conduct responsible research before deciding to commercialize a product. ${ }^{124}$

Because the FDA considers that most food products produced from GM ingredients do not differ materially from conventional foods, it does not impose mandatory labels on GMOs. Where the use of genetic engineering results in a change in food composition, such as the addition of a nutritional property or an allergen, then labeling is required. ${ }^{125}$ The crux of the FFDCA labeling requirement is that all labeling be truthful and not misleading. Labels need not disclose information solely on the basis of the consumers' desire to know. ${ }^{126}$ State efforts to require mandatory labeling due to consumer concerns were found insufficient to justify $1^{\text {st }}$ Amendment restrictions on producers' commercial speech rights. ${ }^{127}$ In the absence of 
any cognizable harm, threat to human health or safety, or some other substantial government interest, the Constitution appears to grant developers of GMOs a right not to speak regarding certain information about their product. ${ }^{128}$

While the United States maintains that its regulatory focus on individual products, sound science, and substantial equivalence is consistent with the findings of the majority of the international scientific community ${ }^{129}$, its multiagency structure has met with substantial criticism. ${ }^{130}$ Some decry the Coordinated Framework as "patchwork" and "haphazard."131 Criticisms focus on inefficiencies and gaps created by the system of shared agency responsibilities. ${ }^{132}$ Because multiple agencies are charged with monitoring different aspects of GMOs, there are risks that significant harms could "slip through the cracks."133 These gaps are widened in the eyes of many due to the fact that certain products do not require approval from each agency, and some require no approval at all. ${ }^{134}$ The lack of comprehensive coverage, mandatory agency approval and independent scientific testing is seen by many as irresponsibly putting the burden on consumers to prove the product is a risk, rather than on companies to prove it is safe. ${ }^{135}$ As consumers are deluged with conflicting scientific reports 
(many of them politically motivated), the transparency promoted by the Coordinated Framework's public access provisions does little to promote regulatory confidence. Aside from environmental and safety concerns, some see the Framework as an economic hindrance. Developers looking to bring new products to market must confront a labyrinth of different agencies, laws and regulations before getting assurance that their product is safe to bring to market. Such delays impose expensive opportunity costs for both industry and the general public. ${ }^{136}$ But perhaps the most damaging aspect of the U.S. Framework is Congress' failure to effectively assign civil liability for damage to people, property or the environment that may result from GMOs. ${ }^{137}$ While laws such as the FFDCA allow the government to institute actions to remedy GMO harms ${ }^{138}$, they lack provisions providing for private causes of action. ${ }^{139}$ State biotech laws likewise have lacked private enforcement provisions. ${ }^{140}$ The result is that private plaintiffs seeking a remedy for GMO harms are forced to look primarily to U.S. common-law principles to redress their grievances.

Absent federal preemption in certain areas, state tort and contract law principles provide the main vehicles for recovery. ${ }^{141}$ A lack of uniformity in state law can bring about contrary results in similar GMO disputes. ${ }^{142}$ Because 
of the capacity of GMOs to create widely dispersed harms (such as broad environmental damage), state law inconsistencies in GMO liability actions could have a negative effect on both the proliferation of the technology and the affordability of insurance.

While the U.S. regulatory system imposes certain duties on GMO manufacturers, contracts provide them with means to limit or escape liability. Intellectual property (IP) protection is central to contracts regarding the sale and planting of GMOs. Seed companies incur tremendous costs to bring new GMO varieties to market, and IP rights help insure a return on that investment. ${ }^{143}$ The United States, in keeping with their obligations under international IP treaties, offers developers of GM crops a sui generis system of IP protection. ${ }^{144}$ U.S. law allows GM crop developers to protect their creations through a combination of patents, plant breeder's rights, and trade secrets. ${ }^{145}$ These protections limit the ability of farmer's to freely plant GM crop varieties, sell or trade GM seed, or to save seeds from

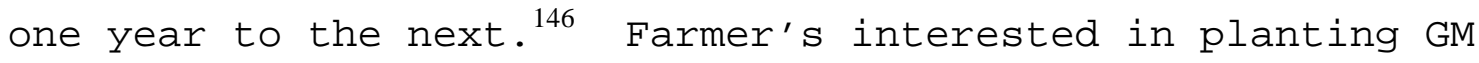
seeds must first enter into a grower's licensing contract with the seed company that specifies the conditions under which the farmer may plant GM seeds. ${ }^{147}$ A farmer who fails to adhere to strict "safe handling" contract requirements 
imposed by the seed company to prevent GM contamination may be liable for breach of contract. Having breached a recognized duty of care, the farmer may also be liable to neighbors in a tort suit (nuisance, negligence, trespass, etc.) for any damage resulting from his crops. ${ }^{148}$

U.S. contract law authorizes sellers of products to disclaim warranties, provide exclusive remedies in the event of a breach of contract terms, or bar the recovery of consequential damages such as loss of profit. ${ }^{149}$ While GM seed companies can limit their liabilities in some disputes through these means, most tort remedies are not extinguished by the application of such contractual provisions. ${ }^{150}$ In addition, such provisions are only effective against buyers or users of a product, and would not bar tort claims instigated by third-party non-users harmed by GMO products. ${ }^{151}$

Interestingly, by aggressively enforcing their IP rights in GM seeds, seed companies may be setting themselves up for broader liability for GMO harms. In Monsanto Canada Inc. v. Schmeiser, 2001 FCT 256 (Fed. Ct. Canada, 2001), Monsanto was able to recover from a 71-year-old Canadian farmer who had grown Monsanto's Roundup Ready soybeans without a license. The farmer claimed the seed had drifted into his farm the previous year and contaminated his crop. 
The trial judge ruled that regardless of how he first obtained the seed, Schmeiser continued to use the GM seeds after a time when he knew or should have known that such use was not permitted. Schmeiser was forced to pay approximately $\$ 12,700$ to Monsanto. For those looking to sue GM seed companies for damages caused by their GMOs, the implication to be drawn from Schmeiser is that if seed companies can claim ownership of GMOs regardless of location or transfer circumstances, then conceivably they should be responsible for any damage they cause. ${ }^{152}$ In the meantime, adherence to the regulatory standards set by governments regarding the planting of GM crops will likely prohibit such IP related liability arguments from prevailing. ${ }^{153}$

There are many tort theories that could provide remedies suited to various types of GMO damage. ${ }^{154}$ These consist of proportional fault-based or joint and several liability schemes (trespass, public or private nuisance, negligence, and products liability) as well as strict liability.

Tort liability is most likely to arise following a situation in which GMOs have escaped the control of an operator, resulting in some type of harm. ${ }^{155}$ The operator represents the body exercising legal control over the GMO at the relevant time of escape. This can include a company 
field-testing a GM crop, a farmer growing GM seeds or someone along the distribution channel that has breached a duty owed to another. ${ }^{156}$ Claims based on GM contamination and resulting damage originate from a variety of claimants. Customers, non-GMO farmers, environmental groups and governments are all potential plaintiffs in GMO suits. While each theory of recovery presents its own difficulties for plaintiffs, one common concern is the difficulty in proving causation. Since GMOs are a new technology, scientific understanding of their implications is, in many areas such as the environment, relatively uncertain. Because multiple factors often combine to cause damage, proving that a GMO was a significant cause of harm in a given case could be extraordinarily difficult. ${ }^{157}$ What follows is a brief description of the elements necessary to establish various tort claims, and their relevance in possible GMO actions.

i. Trespass

While trespass claims have historically not enjoyed a great deal of prominence in agricultural damage disputes, they are often used as a remedy in cases involving airborne contaminants, such as pesticides. ${ }^{158}$ For this reason they 
may have more applicability to a GMO drift case than the more traditional agricultural property damage claims of negligence and nuisance. ${ }^{159}$ In order to sustain a claim of trespass, a plaintiff must show that the actions of the defendant caused a substantially damaging invasion of plaintiff's property. ${ }^{160}$ While trespass requires intent, the intent can take the form of knowledge that one's activities are likely to invade the plaintiff's property. The existence of EPA guidelines requesting farmers to plant a "buffer zone" around their GM crops, coupled with the widespread practice of GMO developers including similar conditions in their seed licensing contracts, could be taken as evidence that harm from GMO drift is reasonably foreseeable.

The determination of whether a trespass took place does not hinge on the size of the intruding element. Damages have been awarded in trespass cases even where invisible particles are involved, as long as there is substantial damage to the plaintiff. ${ }^{161}$ Airborne drift of GMO pollen and cross-pollination of crops from one farmer's land to another's could make the operator of the GM crops liable for trespass. ${ }^{162}$ If defendant's GM seed finds its way onto plaintiff's land and contaminates non-GM crops, that too could create a trespass cause of action. A claimant is 
still required to show that they themselves did not cause the contamination and that it was the defendant's crop that was at fault rather than that of another operator. ${ }^{163}$

The plaintiff must also present evidence of actual damages. While a small amount of GMO contamination is unlikely to cause damage in most instances, there are a few situations in which a claimant could show actual harm. This harm could be demonstrated by showing that plaintiff's land is no longer fit for its previous use (such as organic farming) or that the GMO presence in the plaintiff's crops resulted in a breach of contract or loss of market access. ${ }^{164}$ In the end, for a plaintiff to prevail on a trespass claim, the convergence of a number of favorable conditions is required. Perhaps the greatest obstacle is that for all of the elements of trespass - intent (i.e. knowledge), causation, and actual damage - the burden of proof lies with the plaintiff.

\section{ii. Public Nuisance}

While trespass focuses on invasion of land that interferes with possession, a nuisance claim focuses on interference with use and enjoyment. ${ }^{165}$ The issue is one of reasonable use of land under the circumstances. ${ }^{166}$ While some 
jurisdictions attempt to balance the gravity of the harm against the social utility of the activity in question, others "focus more on ad hoc factors demonstrating a negative impact on the plaintiff's interest." ${ }^{167}$ Nuisance actions can arise out of interference with either the public's or a private individual's use and enjoyment of land. Public and private nuisance law provide the commonlaw remedies in both instances.

A determination of public nuisance allows the government, and in some instances private individuals, to recover damages and enjoin activities that unreasonably interfere with the rights of the general public. ${ }^{168}$ In determining the presence of a public nuisance, courts must consider a number of factors. These include: (a) whether the conduct involves a significant interference with the public health, safety or peace, convenience or comfort; (b) whether the conduct is proscribed by a statute, ordinance or administrative regulation; (c) whether the conduct is of a continuing nature or has produced a permanent or long lasting effect, and (d) whether the actor knows or has reason to know the activity will have a significant effect upon the public right. ${ }^{169}$

In the U.S., public nuisance suits seeking to enjoin the sale and planting of GM crops have already been filed 
against large biotech companies like Monsanto. ${ }^{170}$ Such suits proceed on the theory that GM crops pose an unreasonable and significant interference with public rights because the companies seeking their introduction into the environment have not adequately tested the products for human health and environmental safety. ${ }^{171}$ Threatened injury to the public at large can also come from GMO marketing practices threatening crop exports to countries that have not approved certain GM crop varieties. A GM seed company that fails to take steps to prevent GM seed contamination or to warn growers of the economic risks to grain trade associated with commingling of GMOs and non-GMO seed could be seen as knowingly interfering with the public interest in agricultural trade. ${ }^{172}$ The GM seed industry is responding to these trade related concerns by specifying standards of care, such as buffer zones, and other programs to avoid commingling. The industry is also considering the prospect of selling only GM varieties that have been approved in export markets, as was called for by the American Soybean Association. ${ }^{173}$

$$
\text { Cross-pollination or other contamination of community }
$$
resources with GMOs causing significant environmental or ecological damage is the most likely scenario for implementing a public nuisance suit for damages. ${ }^{174}$ Damage awards would likely be measured in terms of costs incurred 
in cleanup and remediation of environmental harms. In a case involving serious and long-standing environmental harm allegedly attributed to a $\mathrm{GMO}^{175}$, the state of scientific knowledge of a particular GMO's effects as well as the operator's compliance with U.S. regulatory policy will be crucial to the determination of a public nuisance. ${ }^{176}$ While an operator introducing an unapproved GMO variety into the environment may be particularly susceptible to public nuisance claims, an operator complying with the required components of the Coordinated Framework would likely have a formidable defense to a public nuisance action. The lack of U.S. regulatory requirements for independent scientific testing of GMO effects means that an operator's research finding that the GMO posed no substantial risk to the environment could (in the absence of a showing of negligence in conducting the research) also serve as a public nuisance defense.

Even assuming that these defenses are overcome, in order for a plaintiff to recover damages under public nuisance doctrine the harm must be proven. ${ }^{177}$ While genetic marking tests may reveal a particular GMO to be a suspect in a case, environmental and ecological damage usually result from a multitude of factors, scientific understanding of which is limited. Coupled with the variety of operators 
exercising varying degrees of control over GMOs at relevant stages, the attribution of damage to a GMO and responsibility to an operator can be extremely difficult to establish.

In the event a plaintiff succeeds against an operator in a public nuisance suit for damages, apportionment of liability will vary across jurisdictions. In a strictly fault-based liability state, the GMO operator is only liable for damages proportional to their degree of fault. Where many parties play a role in exercising control over GMOs, proving fault of each relevant party in order to recover the full costs of damage brings added legal burdens and costs into nuisance litigation. One defendant's insolvency or lack of insurance can lead to taxpayer dollars having to fill the gaps between the cost of remedying the damage and the amount recoverable from defendants. In states imposing a system of joint and several liability, these problems are averted by allowing plaintiffs to recover the full extent of damage from any of the defendants. In the GMO context, this would most likely leave wealthy biotech companies exposed to the full costs of liability regardless of their degree of fault.

While advantageous to the plaintiff from a cost recovery standpoint, (likely the government - i.e. taxpayers 
- in a public nuisance suit) equitable concerns as well as the resulting disincentive to invest in socially useful technologies caution against wide application of the joint and several liability standard. While GMO defendants found fully liable for environmental damage may thereafter sue codefendants to recover costs, in most instances this will amount to a biotech company suing another GMO operator, such as a farmer or distributor, whose lack of financial resources may make such efforts unprofitable. However, in a joint and several liability system allowing defendants to an initial suit the ability to demonstrate a lesser degree of fault in order to escape full liability, these concerns are mitigated. Placing the burden on defendants to show that they were not at fault lessens the costs of litigation to the plaintiff, while preserving for careful defendants the opportunity to prove they should not have to bear the full costs of remedying GMO damage not attributable to them. In a situation in which there has been harm despite full compliance with regulatory guidelines, forcing the public to bear the costs of any shortfalls in cost recovery appears more equitable.

\section{iii. Private Nuisance}


A private nuisance action gives private parties the ability to obtain injunctions and receive damages for an unreasonable interference with the use and enjoyment of their personal property. ${ }^{178}$ Genetic drift, cross-pollination, and commingling of GMOs with non-GM varieties offer the greatest potential for plaintiffs such as neighboring farmers to institute a private nuisance suit. Many courts have been willing to impose private nuisance liability in the absence of intent, and still others recognize nuisance simply as a condition in need of adjustment, rendering the defendant's degree of care immaterial. ${ }^{179}$ These developments make it easier for plaintiffs to sustain private nuisance actions against GMOs regardless of either their social utility or the implementation of operator safeguards. Some U.S. states have enacted "right to farm" laws codifying the "coming to the nuisance" defense in agricultural settings. However, many of these laws will not insulate farmers engaged in negligent actions (failure to employ a buffer zone could arguably be deemed negligent under certain circumstances), and some have been declared unconstitutional under state law. ${ }^{180}$

A farmer seeking an injunction to prevent a neighboring landowner from planting GM crops will likely have a difficult time succeeding, as U.S. courts are hesitant to 
enjoin otherwise legal actions without proof that harm will result. ${ }^{181}$ Although the loss of organic status or access to export markets can serve as evidence of potential economic harm, these dangers can be mitigated by the defendant landowner's implementation of safeguards such as crop buffer zones. While a court may be receptive to an injunction suit to require that such insulating procedures be undertaken, it is unlikely that a court would enjoin the defendant from planting legally approved GM seed. This leaves a vulnerable party to rely on a remedy of damages in the event of GMO harm.

The use of a private nuisance suit to recover damages to property caused by a GMO can be likened to actions in other agricultural settings. Many states have used nuisance suits to deal with situations involving airborne contaminants such as pesticides and other farm chemicals that present an analogous situation to the danger of property damage from GMOs. ${ }^{182}$ If a farmer plants GM crops without employing a buffer zone, a plaintiff may have a cause of action for negligent nuisance. Such a claim will require a showing that defendant's actions were unreasonable, and compliance with regulatory standards may offer an adequate defense. Where the defendant was under a contractual duty to employ certain safeguards, the plaintiff 
may find it easier to prevail on a claim of intentional nuisance. ${ }^{183}$ The loss of organic certification, and resulting loss of profits, could provide the basis for private nuisance damages in such a situation. ${ }^{184}$

Private nuisance suits may also be employed against GM seed companies who fail to disclose to producers the risks to their exports posed by commingling of GM and non-GM varieties. Companies that fail to prescribe proper safe handling guidelines for growers may also be subject to private nuisance suits by neighbors seeking to recover for lost sales from GM seed contamination. ${ }^{185}$

iv. Negligence

One who fails to act reasonably under the circumstances, and whose failure causes harm to another, may be liable in a negligence action. In order to establish a claim of negligence, a plaintiff will be required to show: (1) the existence of a duty on the part of the defendant to protect the plaintiff from harm; (2) a breach of that duty by the defendant; and (3) actual injury to the plaintiff caused by defendant's failure. ${ }^{186}$ The difficulties in proving the traditional elements of a negligence cause of action - duty, breach, causation and injury - confine the 
negligence remedy to those circumstances where a defendant is likely to be found to have failed to act reasonably in performing their duty. ${ }^{187}$ The pervasiveness of buffer zones and other containment safeguards in GM grower's license contracts, as well as the U.S. regulatory recommendations for implementation of such practices, likely indicate that GM contamination of neighboring fields is reasonably foreseeable. ${ }^{188}$ This knowledge likely places a duty of care on the grower to take acceptable precautions to prevent such harm. The failure of a GMO operator to enact reasonable safeguards to prevent cross-contamination may be grounds for a negligence action when such contamination causes actual harm to a plaintiff. ${ }^{189}$ A defendant complying with contractual or regulatory guidelines is less likely to be found to have breached a duty of care. ${ }^{190}$ Even where a breach has occurred, a plaintiff will still be faced with the difficulty of proving the defendant's GMO caused the harm. ${ }^{191}$ Proof of actual harm can also be hard to establish. Some states require harm to physical property, not mere economic loss, to recover in a negligence action. ${ }^{192}$ Where the numerous burdens required to sustain a successful negligence claim appear too difficult for a plaintiff to overcome, a products liability cause of action may be an appropriate alternative remedy . 
v. Products Liability

GM seed companies which fail to alert buyers or growers to the risks posed by GMOs may be liable in a products liability action. ${ }^{193}$ Products liability may also provide a remedy in instances where damages are due to a defect in the GMO itself. ${ }^{194}$ A company's failure to notify operators of GMOs that their products may cross-pollinate with non-GMO varieties, and how to prevent such occurrences, could lead to a determination that the product contained inadequate instructions and was therefore defective. Of note is that where GMOs exhibit pesticidal properties, state tort claims premised on inadequate labeling may be preempted by compliance with FIFRA requirements. ${ }^{195}$ A manufacturer who makes negligent or intentional misrepresentations to regulators or buyers regarding the safety of their product or its fitness for a particular use may be responsible for damages in a products liability action. For example, if farmers planting StarLink corn that had not been approved for human consumption were not told of its status by Aventis, the manufacturer, they could commence a products liability action to recover the resulting decrease in 
marketability of their crop. ${ }^{196}$ A GMO destined for consumers that failed to warn of an allergen could also provide the vehicle for a successful products liability action. ${ }^{197}$

While some producers may be subject to strict liability for harms caused by their product, a number of fault-based exceptions can allow producers to escape full responsibility. These include: compliance with applicable laws and rules; utilization of the best available scientific technology (BAT) or evidence to determine product safety; and a showing that the product was not defective when placed on the market. In addition, the consumer must prove the existence of the product defect, actual injury, and the causal nexus between the two.

vi. Strict Liability

Strict liability operates to hold a defendant liable for harm resulting from their activities regardless of the defendant's degree of fault. Equity concerns as well as the lack of a deterrent element have historically restricted the application of strict liability to defendants engaged in activities recognized as "abnormally dangerous."198 Given the growing presence of GM crops in agriculture ${ }^{199}$ and the lack of a U.S. regulatory ban on GM crops, it is unlikely 
that a court would determine the practice is abnormally dangerous. A plaintiff alleging harm from an approved GMO variety will likely be required to show fault, but where an unapproved GM variety is the source of harm, strict liability may apply. ${ }^{200}$

Some courts have been willing to look to the character of the surrounding land use in determining whether an activity is abnormally dangerous. ${ }^{201}$ In the case of chemical sprayings, most courts require proof of operator negligence before awarding damages. ${ }^{202}$ However, a defendant who sprays herbicide on their property resulting in damage to a neighboring landowner's crops can be held subject to strict liability. ${ }^{203}$ Crop dusting can also entail strict liability for harms to neighboring property. ${ }^{204}$ The benefits to the spraying farmer of increased crop yields may not justify the damage to the neighbor's crops. ${ }^{205}$

These approaches to harmful airborne chemical contaminants can be likened to the dangers posed by GMO drift and other airborne methods of GM contamination. Accordingly, a farmer planting GM crops in the hope of increased yields may be strictly liable for GMO damage to neighboring landowners. ${ }^{206}$ While property law usually upholds a landowner's right to make lawful use of their property, a farmer planting GM crops in an area dominated by 
organic farmers may be introducing an "alien substance" and engaging in "ultrahazardous activity" justifying the imposition of strict liability. ${ }^{207}$ By subjecting their organic farming neighbors to risks that they themselves are not reciprocally subjected to, the GMO farmer's practices may create a risk imbalance that can best be handled applying a strict liability standard. ${ }^{208}$

While classifying GMOs as an abnormally dangerous activity may be justified in certain narrow instances, specialized economic harms are unlikely to justify broad scale imposition of strict liability on GMO operators absent clear scientific evidence demonstrating the unreasonable health or environmental risks of GM crops.

B. GMO Policy in the European Union

E.U. policy decisions regarding GMO products are as focused on the processes used to produce the products as they are with the products themselves. ${ }^{209}$ This "process" approach is in contrast to the American "product" approach reliance on "substantial equivalence." The close European connection to traditional food production processes, combined with a historical and cultural distrust of biotechnology, have led to greater skepticism in Europe over 
the safety of foods produced through genetic engineering. ${ }^{210}$ In response to this skepticism, E.U. GMO decisions are guided by application of the precautionary principle. ${ }^{211}$

A fixture in numerous environmental treaties, ${ }^{212}$ the precautionary principle holds that scientific uncertainty regarding potentially dangerous health or environmental effects from GMOs should not preclude action being taken in order to prevent harm. ${ }^{213}$ While seemingly benign, the scope of the principle has historically been ill defined, leading to criticism that its application to GMOs and other products constitutes an arbitrary and discriminatory barrier to trade. ${ }^{214}$ As the E.U. strives toward a precautionary approach incorporating more fixed standards to guide regulatory decisions, ${ }^{215}$ stringent regulation of GMOs at the Community level continues. The fears expressed through the application of the precautionary principle have blossomed into a regulatory structure that treats products produced by genetic processes as "novel goods," a special category in need of unique regulation. ${ }^{216}$ Community harmonization of member state law in this area is accomplished primarily through the use of "regulations" and "directives". 217 E.U. regulations are community-wide legislative proposals setting forth legal obligations binding on Member 
States. These proposals are directly applicable in Member States and specify not only the ends to be achieved, but the means by which to achieve them. In contrast, Directives specify the ends to be achieved, but allow the member states flexibility regarding the means employed to achieve these ends under their national legal systems. ${ }^{218}$ Directives have emerged as the favored means of E.U legislative action through application of the "subsidiarity" principle, which proposes to limit Community action to areas where measures cannot sufficiently be undertaken by Member states alone. ${ }^{219}$

The first major E.U. legislative proposal to deal with GMOs came in 1990 with the passage of Council Directive $90 / 220 .{ }^{220}$ Directive $90 / 220$ was enacted in response to the demands of European biotechnology companies distraught by the complex web of Member state regulatory regimes that they believed disadvantaged them with respect to their foreign competitors. ${ }^{221}$ Directive $90 / 220$ and its 2001 replacement, Directive 2001/18, 222 harmonized Community procedures for GMO approval and market access. 223 "Novel foods" legislation in the form of Council Regulation 258/97 was enacted to cover sterile products derived from GMOs, including novel foods consisting of, containing, or produced from but not containing GMOs. ${ }^{224}$ 
Before a company can release a GMO into the territory of a Member state, they must notify the Member state's competent authority. The notification must provide the authorizing party with all significant information about the GMO, including a detailed risk assessment report ${ }^{225}$ and a technology profile revealing the GMO's relevant properties. ${ }^{226}$ If the Member state's authorities approve the company's GMO in the specified ninety-day time period, they forward the company's application to the European Commission, which distributes it to all Member states for feedback. If no Member state objects, the Member state originally notified may place the GMO on the market, and it may thereafter be used throughout the Community without requiring further notification. ${ }^{227}$ A GMO has never been unanimously approved by all Member states. ${ }^{228}$

Member state objections to the placing on the market of a specific GMO variety prompt a dispute resolution process. The process requires a committee of Member state representatives to give qualified majority approval to a Community-wide release. Failing committee approval, the proposal is forwarded to the Council. If three months pass and the GMO proposal has not been rejected by a qualified majority of the Council, it is sent to the Commission to be approved for Community release. ${ }^{229}$ Before the E.U. issued its 
current moratorium on GMO approvals in June of 1999, only fourteen GMOs were approved under Directive 90/220. This is in stark contrast to the 58 GMOs currently approved for market in the U.S. ${ }^{230}$

In addition to the arduous approval procedure, GMOs currently available in the E.U. are stringently regulated by a variety of Community-wide legal instruments. ${ }^{231}$ Mandatory labeling and Member state notification are required by the E.U. before any product containing GMOs can be placed on the market. ${ }^{232}$ Recognizing the difficulties non-GMO producers face in segregating their products from GMOs, any product containing less than a one percent "adventitious presence" of GM soya or maize material need not carry a label alerting consumers that the product contains GMOs. ${ }^{233}$

Issues concerning the scope of Community intellectual property protection for GM plant varieties are settled primarily by the European Patent Office. As signatories to the WTO TRIPS Agreement, all E.U. states are obligated to provide IP protection for GM plant varieties either through patents or an effective sui generis system. ${ }^{234}$ These IP protections impact GMO contract terms and private party rights in much the same manner as in the U.S., and govern party liability absent legal codes, statutes or public policy justifications to the contrary. 
While liability for GMO harms can vary greatly depending on how circumstances are dealt with under Member State law, liability principles in some areas have been defined on a Community-wide basis. These areas include E.U. products liability law, as well as environmental liability proposals currently under legislative consideration. ${ }^{235}$

GMO liability for harms to the health or property of E.U. consumers may be best dealt with under Community products liability law. Producer liability for defective products is governed by Council Directive 85/374/EEC, as amended by Council Directive 1999/34/EC. ${ }^{236}$ These directives allow the Member states to utilize their existing civil and common law remedies to distribute liability in accordance with the directive's requisite standards. Directive 1999/34/EC imposes strict liability on producers for harms to consumers and their property, with joint and several liability applied when multiple producers are involved. ${ }^{237}$ The "producer" liable for a defective product may include: any party whose name or trade markings grace the products packaging; the product's importer; any party involved in the production process; or the seller of the product in the event the producer cannot be identified. The plaintiff carries the burden of proof with respect to demonstrating 
actual harm, the existence of a defect in the product, and the causal relationship between the harm and the defect. ${ }^{238}$ Exemptions from strict liability may apply in certain cases, including situations where the defect is due to compliance of the product with mandatory regulations issued by the public authorities; the state of scientific and technical knowledge at the time the product was put into circulation was not such as to enable the defect to be discovered (Member States legislation may derogate on this point); and where the defect causing the damage was not present when the product was placed on the market. ${ }^{239}$ The Directive also contains a three-year statute of limitations on claims as well as a liability cap allowance of not less than ECU 70 million.

Interestingly, due to the extensive E.U. approval process, (detailed labeling and disclosure requirements, independent Member State risk assessments) plaintiffs seeking to hold the manufacturer of a Community-approved GMO liable for it's harms appear less likely to prevail than in the U.S. For example, a company whose GMO produced an unanticipated allergic reaction after undergoing thorough EFSA and Member State evaluations appears better equipped to demonstrate they took every reasonable precaution to guard against adverse product effects. The consent to release of 
the GMO by Member state authorities would appear to be a more persuasive exemption from strict products liability in the E.U. than in the U.S., given the U.S. regulatory reliance on company "product stewardship" 240 to provide assurances of product safety. Harm to private property from defective GMOs, such as soil damage or crop damage, could also provide the basis for E.U. products liability actions, provided the property was used primarily for private use and consumption. ${ }^{241}$

Economic damages such as consequential damages associated with the loss of crop certification or contract profits fall outside the scope of damages recoverable under 85/374/EEC. Directive 85/374/EEC only allows recovery for damage to property "intended for private use or consumption," 242 so Member State municipal legal principles (tort law, civil code provisions, etc.) likely provide the best opportunity to recover GMO damage to commercial interests. ${ }^{243}$

The E.U. is currently in the process of refining a proposal to harmonize Member state law in regards to environmental liability that would apply to damage caused by GMOs. ${ }^{244}$ The E.U. considers this legislation to be a prerequisite to lifting the current ban on new GMO approvals. ${ }^{245}$ The objective of the current proposal is to "establish a 
common framework for the prevention and remedying of environmental damage at a low cost to society." ${ }^{246}$ In pursuit of that goal, the proposal attempts to clarify the scope of environmental damage to be remedied, as well as proper standards of liability to be applied in various instances. ${ }^{247}$ The proposal purports to embody the "polluter pays" principal, which holds that the party responsible for creating the environmental harm or risk of harm should be forced to bear the costs of prevention, cleanup, and restoration.

Many environmental groups had hoped that a "polluter pays" approach to the proposal would contain the following standards, among others: (1) hold operators strictly liable for damage they cause, regardless of regulatory compliance; (2) require operators to procure environmental damage insurance or contribute to the establishment of a financial guarantee in case of operator insolvency; (3) define environmental damage broadly to encompass biodiversity damage to non-protected areas; (4) apply retroactively; and (5) establish private rights to compensation in the event of economic loss caused by environmental damage.

The current proposal fulfills none of those hopes, instead providing a system where companies can pursue ventures without fear of extensive liability regardless of 
fault. Nonetheless, it is intended to act as a baseline level of protection, allowing Member states to apply more stringent regulations. ${ }^{248}$ More stringent laws could allow for additional liable parties, varying cost apportionment, and broader environmental coverage than that described in the proposed Directive. ${ }^{249}$ For example, under the Directive, operators liable for damage can include anyone exercising control over the GMO. Municipal legislation might eliminate farmers from the definition of "operator" in the GMO context, thus leaving GMO developers as the only responsible parties under national law and forcing them to rely on specific fault-based exceptions to extinguish their liability.

Under the current directive proposal, each Member state is required to designate an authority responsible for the assessment and cleanup of environmental damage. ${ }^{250}$ Environmental damage is defined to include serious adverse consequences to biodiversity conservation, as well as potential or actual harm to the public as a result of soil or subsoil contamination. ${ }^{251}$ The directive will exclude damage of a widespread or diffuse character that does not allow for the establishment of a causal link between operator and harm. ${ }^{252}$ When damage or the threat of damage is identified, either by private parties or the designated 
authority, the authority can either request the operator to take action, or it can take action itself and then recover costs from the operator. ${ }^{253}$ The operator will be liable for the costs of prevention, cleanup, and recovery, as well as the costs associated with the assessment of damage. ${ }^{254}$ Multiple operator liability under the directive may be addressed via a joint and several or a fault based scheme. ${ }^{255}$ Many exceptions work to relieve an operator of liability, including using BAT, acting in accordance with current scientific knowledge, and complying with applicable permits and legal requirements. ${ }^{256}$ A five-year statute of limitations will bar latent claims. ${ }^{257}$ Where damage is to biodiversity, fault must be shown before a party will be held liable. ${ }^{258}$ Insurance is encouraged, rather than required, and Member states retain the option to establish a financial mechanism to assist in remedying damage in the event the operator is insolvent or no operator can be identified. ${ }^{259}$ The directive will neither apply retroactively, ${ }^{260}$ nor create private rights to compensation for economic losses. ${ }^{261}$

Many environmental groups feel the proposal's limited scope and numerous exceptions will in practice fail to hold operators liable for damage they cause. The inclusion of an 
"authorized use" exception from operator liability ${ }^{262}$ could prove problematic, forcing the issuing government to play the dual roles of prosecutor and defendant in an environmental liability action. Even where the government decides to act to restore an area damaged by an operator in compliance, taxpayers, not the operator, will pay the costs. ${ }^{263}$ Government and industry, however, see it as an important practical step to encourage responsible economic growth, as well as one that will foster closer industry/regulatory cooperation and accountability. The proposed directive allows GMO operators to pursue action with enormous potential social utility with the assurance that their good faith efforts to ensure product safety will not subject them to devastating liability costs. By restricting the scope of liability to situations involving significant environmental damage, with damages valued at the costs of ecological restoration, ${ }^{264}$ insurance markets are better able to evaluate the risk of policyholder liability. This contributes to more affordable insurance premiums, especially for GMO companies that can demonstrate to insurers that their products are unlikely to cause significant or concentrated harms.

The specific environmental risks posed by GMOs, such as gene flow and loss of habitat or biodiversity, are unlikely 
to be addressed within the ambit of the proposed directive. While genetic marker technology may allow authorities to trace the diffuse harms to biodiversity posed by GMOs, it remains unclear how the existence of "serious adverse effects" to biodiversity will be determined. The limited definition of biodiversity contained in the directive does not address harms to areas not designated for protection or conservation under either Community instruments or national law. ${ }^{265}$ Even in the event the competent authority identifies a causal nexus between a GMO and serious adverse effects on biodiversity, significantly damaging ecological impacts are unlikely to be discovered within the directive's five-year claim limitation.

In addition, those attempting to hold operators liable for harms to biodiversity must prove operator fault. "Authorized use" exceptions aside, establishing the extent to which a GMO is at fault in an ecological disaster will be extremely difficult, creating expensive "deep pockets" litigation involving competing expert scientific opinions. The costs of such litigation divert resources away from the bio-remediation efforts - assuming such efforts are both viable and capable of accurate valuation. ${ }^{266}$ In the event harm to biodiversity is identified, authorities may be reluctant to take action due to the complexity of the task 
and the lack of certainty that costly efforts will prove successful in restoring ecological damage. While operators can be forced to contribute to the costs of alternative cleanup and restoration efforts when authorities deem such action more practicable, this is of limited effect in dealing with GMO damage. The biological nature of GMO harms increase the danger that if a specific situation is not remedied its effects will have much broader implications than, for instance, a chemical spill or other environmental harms more easily contained.

Failure to hold operators liable for long-term, broad scale damage to biodiversity puts added pressure on regulatory authorities charged with protecting the environment to ensure GMO products are safe. Since authorities such as the EFSA are unlikely to be as knowledgeable about a product's risks as the developer, approvals of new varieties will be slowed while regulators institute long and costly risk assessments more suitably undertaken by the GMO developer. This creates an inefficient allocation of costs without added assurances of safety, as well as increased disruption of trade. While it is acceptable to note that long-term harm may not be foreseeable by any party, and that society should bear the costs associated with scientific endeavors 
promising broad social benefits, five-years is a rather abrupt time period in which to identify and assess ecological damage from GMO endeavors. By giving carte blanche to operators complying with the terms of acceptable use, companies have less incentive to undertake preventative measures or pursue a policy of "product stewardship."267 Thankfully, operators acting in a negligent manner will not be excused from liability by complying with applicable regulatory guidelines. Because operators are unlikely to risk facing the extensive liability implications of acting without the needed regulatory consent, the net effect of the proposed directive is to elevate individual Member state negligence law will to the de facto standard for GMO operator liability. While hardly harmonized throughout the E.U., an assessment of negligence law principles applied in various jurisdictions allows parties to ascertain the acceptable standards of care needed to reduce actor uncertainty and encourage safe practices. Given current levels of scientific ecological understanding, perhaps evolving negligence law principles are the only practical way to balance the cost allocations associated with the benefits and risks of GMOs.

As insurance markets gain experience with pricing risks liability policies tailored to the GMO industry should 
become more affordable and directly accessible in actions to recover cleanup and recovery costs. In time, insurance innovations such as secondary markets for risk trading and securitization, mandatory environmental liability insurance, and financial responsibility requirements (FRRs) can help ensure that the full costs of broad scale ecological damage from GMOs are not borne solely by the public. ${ }^{268}$

C. Multi-Lateral Instruments Shaping GMO Liability Rules

While individual nations often take vastly different regulatory approaches to GMOs, ${ }^{269}$ the importance of GMOs to world agricultural trade and development goals means that international agreements and institutions increasingly play a larger role in determining the scope of GMO regulations in their party nations. ${ }^{270}$ Foremost among these international regimes is the World Trade Organization (WTO), a body containing the principal players in the biotechnology sphere. While "(t)here are currently over 30 ongoing multilateral discussions concerning biotechnology" ${ }^{271}$, the WTO functions as the primary body charged with resolving disputes affecting international trade. ${ }^{272}$ These disputes comprise a wide range of trade related issues including acceptability of certain safety regulations, denials of 
market access, and protection of intellectual property rights. ${ }^{273}$

Within the WTO structure, three side agreements - the TBT, SPS, and TRIPS Agreements - play a sizeable role in establishing acceptable regulatory standards applicable to GMOs. ${ }^{274}$ WTO Dispute Panel decisions interpreting these agreements in conjunction with relevant provisions of the General Agreement on Tariffs and Trade (most notably GATT Article XX exceptions) can have a large effect on national GMO regulatory policy. ${ }^{275}$ Nations unwilling to conform their regulatory policies to acceptable WTO standards can find themselves facing diminished trade prospects and the suspension of valuable tariff concessions. In comparison to other international agreements hampered by ineffective enforcement provisions, the WTO has often been able to bring Member nation policies into compliance with its requirements. ${ }^{276}$

The harmonizing of regulatory guidelines in order to conform to interpretations of WTO side agreements can contribute greatly to the promulgation of applicable liability standards for GMOs. Such harmonization, however, can only take place if the WTO retains its position as the acknowledged moderator of global trading conditions, an outcome that looks increasingly less likely by the day. ${ }^{277}$ 
Assuming the continued vitality of the WTO, the dispute settlement process has so far proved incapable of resolving the impasse created by applications of the precautionary principle to justify trade-distorting import bans. ${ }^{278}$ The long-term viability of the current incarnation of the precautionary principle is threatened, as the principle is likely to be a central component of future WTO disputes. In fact, the U.S. has recently indicated that it intends to follow through on its threat to institute WTO dispute proceedings against the E.U. The complaint will allege that the E.U. de facto GMO approval ban, enacted pursuant to E.U. precautionary principle interpretation, amounts to an unjustifiable trade barrier. ${ }^{279}$ Prior WTO cases contesting arbitrary or discriminatory E.U. application of the principle ("Beef Hormones") ${ }^{280}$ suggest a U.S. victory. ${ }^{281}$ Current international standards providing the basis for measures qualifying as "scientifically justified" exceptions to GATT rules can be found within the Codex Alimentarius Commission (Codex) standards on food safety, pesticide residues, and science-based risk assessments, ${ }^{282}$ and the plant health standards of the International Plant Protection Convention. ${ }^{283}$ The standards set forth in these sources do not support the existing precautionary principle risk assessment policies undertaken by the E.U. regarding GMOs. ${ }^{284}$ 
Current international standards support a product, not process, regulatory focus with an emphasis on science-based risk analysis building on the concept of substantial equivalence. ${ }^{285}$ While the WTO allows the E.U. to maintain a higher level of protection in instances where the international standard fails to offer an "appropriate level of sanitary or phytosanitary protection," ${ }^{286}$ the E.U. currently has no sufficient scientific evidence of adverse health effects to justify their ban. ${ }^{287}$ Article XX(g) may allow the E.U. to claim biodiversity as a natural resource in need of protection, but the lack of discernable limits on such a justification, as well as the limited definition given to biodiversity in the current E.U. Proposed Directive on Environmental Liability, undermine the persuasiveness of this interpretation. Given the immense political opposition to biotech foods in the E.U., bucking international standards is of little consequence to officials in charge of setting regulatory policy. Regardless of the outcome of any WTO GMO dispute, relenting under WTO pressure is not a political option for E.U. leaders. ${ }^{288}$

The prevalence of the precautionary principle in environmental treaties such as the Cartegena Protocol to the Convention on Biodiversity (CBD), and the E.U.'s obligation to honor the commitments imposed on it by those treaties, 
point to the need for greater clarification of the criteria used in the principle's application. ${ }^{289}$ Added transparency and scientific underpinnings to the principle can help to distinguish health and environmental caution from protectionism, thereby allowing the dual international goals of biosecurity and trade promotion to coexist.

Alongside precautionary health and environmental objections are the legitimate economic concerns of the developing world. The TRIPS obligation to grant either patents and plant breeder's rights or sui generis protection to GMO varieties may be seen as too large a risk to the long term sustainable agricultural survival of many developing country farmers. Governments unwilling to see their small farmers run out of business by large agricultural companies (as allegedly occurred in many developing countries following the "Green Revolution" of the 1970's) may ban the sale or importation of GM seeds. ${ }^{290}$ The flexibility of current WTO instruments to handle trade restrictions imposed as a means to safeguard cultural heritage or economic development goals is uncertain, and efforts to dismantle developing country efforts at maintaining needed farmer security will no doubt instigate more debilitating anti-WTO protests. 
International agencies such as Codex are working hard to standardize acceptable approaches to GMO risk assessments in order to ensure a greater degree of state regulatory uniformity. ${ }^{291}$ While the standards are nearly set, states must adopt them in practice in order for GMO operators to have clear guidance on appropriate standards of care, including the level of regulatory compliance required to exempt them from liability. To the extent states continue to maintain fractured regulatory approaches to GMOs, liability principles will be divergent and uncertain.

\title{
Part III
}

Conclusions and Recommendations

\author{
Genetically modified organisms have the potential to \\ generate severe adverse effects on human health and the \\ environment while simultaneously creating numerous trade and \\ financial difficulties. But the contributions that GMOs can \\ make to a healthier, more sustainable future are enormous. \\ No single regulatory structure is appropriate to tackle the \\ diverse concerns presented by GMOs, and no single set of \\ liability principles can effectively balance the rights and \\ obligations of parties in the vast array of GMO dispute \\ contexts. An effective liability system is but one
}


necessary component in an inter-related approach to dealing with the perils and promises of biotechnology.

A successful approach must combine efforts in the areas of research, risk assessment, risk management, commercialization and release, monitoring, and dispute resolution. Because liability standards only come into consideration following a breakdown in another area of focus, their principles are necessarily a function of the cost/benefit allocations that have taken place along the GMO continuum.

In the coming years, as states attempt to elaborate international rules and procedures in respect of liability for domestic and transboundary GMO harms, ${ }^{292}$ greater familiarity with the implications of the technology will help to settle many of the perplexities plaguing current GMO harmonization efforts. The new Codex standards for risk assessment demonstrate that the international scientific community is rejecting the E.U. regulatory focus on process in favor of the product-focus approach favored in the U.S. Broad international acceptance of standards such as these can bring the clarity and transparency needed to distinguish scientific justifications for GMO policy from protectionist ones. 
Further clarifications of vague standards such as the precautionary principle and the polluter pays principle will assist in the development of regulatory frameworks that offer more guidance to GMO operators on appropriate standards of care. International agreements delineating the scope of environmental harms that trigger operator liability are also required. Harms to broad concepts such as biodiversity or habitat will need to be defined in greater detail so as that objective cost valuations can be determined. An intergovernmental task force on biotechnology harms, under UN or WTO auspices, can assist in refining such concepts. For now, the standards set forth in the proposed E.U. directive are sufficient. Either the costs incurred in preventing an imminent environmental danger, or those expended during cleanup and restoration can serve as benchmarks for the assessment of damages.

As more states build the institutional and technical capacities necessary to evaluate the risks posed by GMOs, the international community will undoubtedly need to exhibit greater co-operation regarding safety assessments, product labeling requirements, and monitoring. State development and implementation of mechanisms tailored to GMOs akin to those in the CBD and the Cartegena Protocol can speed the development of liability principles. 
Mechanisms such as a one-stop Bio-Clearinghouse for non-sterile GMOs and a streamlined advanced informed agreement (AIA) protocol for securing operator and importing government consent to a GMO release can provide baseline procedures to evaluate both a GM variety's environmental safety and a GMO operator's acceptance of appropriate use guidelines. The Bio-Clearinghouse could be responsible for independently determining the relative environmental safety of a new GM variety. It should provide conditions of acceptable use for new GMO varieties as a component of its evaluation. In order to safeguard threats to habitat loss and biodiversity, conditions can include zoning requirements prohibiting the planting of GMO varieties in close proximity to wild relatives to reduce the risk of gene flow, as well as buffer zone or terminator seed ring requirements. ${ }^{293}$

Where States feel their environments are particularly susceptible to the risks of harm posed by a GMO variety, they can present their justifications to the Clearinghouse for its review, and ask permission to modify the baseline conditions of use to better accommodate their respective environment. Any operator complying with the terms under which consent to release is granted receives an exemption from liability similar to that contained in the proposed E.U. Environmental Liability Directive. Those operators 
acting outside the bounds of acceptable use will be subject to liability either on the basis of fault or under a joint and several apportionment, allowing for diminished liability where an operator can establish they did not contribute to the full extent of the harm.

The AIA can be used to minimize the dangers of transboundary harm arising where a use acceptable in one state is objectionable to a neighbor state. Bordering states can fund a mutual bio-remediation response authority charged with monitoring terms of use and preventative measures, as well as undertaking necessary cleanup efforts. This can be funded through public funds or industry contributions. The authority can take the necessary immediate action and recover costs from the responsible operators where such action would be feasible. By giving GMO operators fixed standards of care by which to abide, insurance companies will be better able to evaluate risks posed by individual policyholders and offer insurance plans tailored to their needs. GMO damage insurance can be mandated by countries lacking the funds to provide an adequate governmental response and recovery authority, with direct action to recover insurance costs immediately available to plaintiffs in order to speed remediation efforts. 
Recovery of economic damages from GMO contamination should continue to be dealt with under national common or law or civil code provisions, taking into account relevant standards of care and the circumstances surrounding adjacent land use. The implementation of expensive containment and segregation efforts will likely have to be undertaken and funded in large part by biotech companies, in order to ensure the integrity of the food supply that is demanded by discriminating global consumers.

Refined GMO food products have not yet presented a danger to public health. Although mandatory labeling will impose costs on both producers and consumers, until consumer suspicion of GM foods wanes through periods of extended safe use, labeling will likely be a political, if not a safety, necessity. Current products liability standards for harms to human health will accommodate biotech concerns, as regulatory oversight and product stewardship continue to prove effective at ensuring public safety.

Genetically modified organisms offer tremendous promise for achieving global sustainable development goals. Current international efforts at regulatory harmonization and capacity building are accelerating the development of effective, balanced GMO liability principles. By taking a holistic approach to biotechnology regulation, including the 


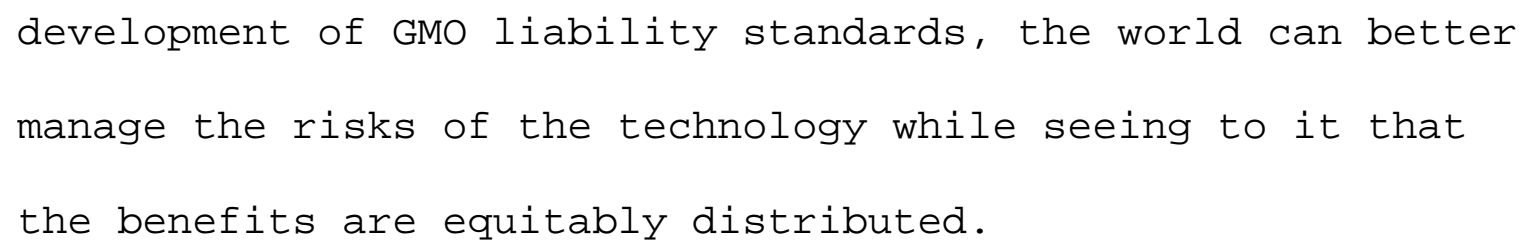
${ }^{1}$ Sanford E. Gaines, Triangulating Sustainable Development: International Trade, Environmental
Protection, and Development, 32 Envtl. L. Rep. 10318 (March 2002) (commenting that "the relationship
between liberalized patterns of international trade and sustainable development has emerged as a matter of
fierce controversy in civil societies and intergovernmental diplomacy.")

${ }^{2}$ Nick Smith, Seeds of Opportunity: An Assessment of the Benefits, Safety, and Oversight of Plant Genomics and Agricultural Biotechnology, Report Prepared for the Subcommittee on Basic Research, Committee Print 106-B, Transmitted to the House Committee on Science, April 13, 2000 available at http://www.house.gov/science/smithreport041300.pdf (Feb. 12, 2003) (summarizing stringent approach to biotech regulation in the U.S); Marc Victor, Note, Precaution or Protectionism? The Precautionary Principle, Genetically Modified Organisms, and Allowing Unfounded Fear to Undermine Free Trade, 14 Transnat'l Law. 295, 319 (Spring 2001) (describing the E.U. use of the precautionary principle as a barrier to trade); Higginbotham v. Monsanto Co., amended complaint, count V, Case No. 1:99cv03337 (D.D.C.), P 199, information at http://www.centerforfoodsafety.org/LegalUpdateAug20001.html (alleging Monsanto, the biotech giant, conspired to fix prices on its GM seeds and failed to adequately test its seeds for human health and environmental safety); BBC News, Famine and the GM debate, BBC News, November 12, 2002, at <http://news.bbc.co.uk/2/low/africa/2459903.stm> (discussing African nations refusal to accept GM food aid in November 2002).

${ }^{3}$ Todd Johnston, The Role of International Equity in a Sustainable Future: The Continuing Problem of Third World Debt and Development, 6 Buff. Envtl. L. J. 35, 40 (Fall 1998) (describing the "Ladder Theory" of stages in development explored in Joseph E. Stiglitz, Economics 1118 (1993).)

${ }^{4}$ Jonathan Brooks, Organisation for Economic Co-operation and Development, The Uruguay Round Agreement on Agriculture: The Policy Concerns of Emerging and Transition Economies (2000) at 14, available at http://www.oecd.org/pdf/M00004000/M00004814.pdf (February 5, 2003) (detailing the importance of a strong agricultural trading market to emerging and transition economies).

${ }^{5}$ Other issues are explored in WTO news bulletin TE/019-July 1997, summarizing discussions at a May 1997 WTO symposium with non-governmental organizations (NGOs) on Trade, Environment and Sustainable Development, at http://www.wto.org/english/tratop_e/envir_e/te019_e.htm (February 3, 2003)

${ }^{6}$ Convention on Biological Diversity, (5 June 1992) Article 2, at http://www.biodiv.org/doc/legal/cbden.pdf (Jan. 23, 2003) (efforts aimed to reduce potential threats to biodiversity and ensure the safety of biotechnology).

${ }^{7}$ Sean D. Murphy, Biotechnology and International Law, 42 Harv. Int'1 L.J. 47, 50 (2001).

${ }^{8}$ Kelly A. Leggio, Comment, Limitations on the Consumer's Right to Know: Settling the Debate over Labeling of Genetically Modified Foods in the United States, 38 San Diego L. Rev. 893, 904-905 (Summer 2001) citing William K. Purves et al., Life: The Science of Biology 402 (3d ed. 1992). See also J. Howard Beales III, Modification and Consumer Information: Modern Biotechnology and the Regulation of Information, 55 Food \& Drug L.J. 105, 105 (2000). 
${ }^{9}$ The FDA has characterized the processes utilized for genetic engineering as existing on a continuum, proceeding from traditional breeding methods to today's practice of transplanting genes from different species. "The genetic modification techniques used to develop new plant varieties constitute a continuum. Traditional breeding typically consists of hybridization between varieties of the same species and screening for progeny with desired characteristics. Such hybridizations only can introduce traits found in close relatives. Breeders have developed or adopted a number of techniques to expand the range of genetic variation available to them. These techniques introduce variation either by using mutagenesis to alter the genome or by introducing or modifying DNA segments, including DNA segments derived from other organisms." Department of Health and Human Services, Food and Drug Administration, Statement of Policy: Foods Derived From New Plant Varieties, Docket No. 92N-0139, 57 Fed. Reg. 22984, 22985-86 (May 29, 1992). A collaborative report of eight national academies of science, the U.S. National Academy of Sciences among them, had this to say on differences between conventional and modern genetic engineering: "Traditional plant breeding methods include wide crosses with closely related wild species and may involve a long process of crossing back to the commercial parent to remove undesirable genes. A feature of GM technology is that it involves the introduction of one or, at most, a few well-defined genes-rather than the introduction of whole genomes or parts of chromosomes as in traditional plant breeding. This makes toxicity testing for transgenic plants more straightforward than it is for conventionally produced plants with new traits, because it is much clearer what the new features are in the modified plant. On the other hand, GM technology can introduce genes from diverse organisms, some of which have little history in the food supply." Transgenic Plants and World Agriculture 15 (July 2000), Report prepared under the auspices of the Royal Society of London, the U.S. National Academy of Sciences, the Brazilian Academy of Sciences, the Chinese Academy of Sciences, the Indian National Science Academy, the Mexican Academy of Sciences and the Third World Academy of Sciences, available at http://bob.nap.edu/html/transgenic/safety.html (Feb. 12, 2003)

${ }^{10}$ See Murphy, supra note 7, at 50, noting that this feat was accomplished in 1986. See also Jeremy Rifkin, The Biotech Century 14 (1998).

${ }^{11}$ On rDNA, the FDA has stated: "Recombinant DNA techniques involve the isolation and subsequent introduction of discrete DNA segments containing the gene(s) of interest into recipient (host) plants. The DNA segments can come from any organism (microbial, animal, or plant). In theory, essentially any trait whose gene has been identified can be introduced into virtually any plant, and can be introduced without extraneous unwanted genetic material. Since these techniques are more precise, they increase the potential for safe, better-characterized, and more predictable foods." Id. At 22985

${ }^{12}$ David J. Schnier, Genetically Modified Organisms and the Cartegena Protocol, 12 Fordham Envtl. L.J. 377, 379 (Spring 2001). The Cartegena Protocol adopts the terminology 'LMO.'

${ }^{13}$ Clive James, International Service for the Acquisition of Agri-biotech Applications (ISAAA), Global Status of Commercialized Transgenic Crops: 2002, ISAA Briefs No. 27: Preview (Jan. 16, 2003) available at http://www.isaaa.org/ (Feb. 11, 2003), providing highlights from the 2002 report. The report states that "(d)uring the seven-year period 1996 to 2002, global area of transgenic crops increased 35-fold, from 1.7 million hectares in 1996 to 58.7 million hectares in 2002."

${ }^{14}$ Id. Stating that "(g)lobally, the principal GM crops were GM soybean occupying 36.5 million (hectares) has. in 2002 (62\% of global area), followed by GM corn at 12.4 million has. (21\%), transgenic cotton at 6.8 million has. (12\%) and GM canola at 3 million has. (5\%)."

${ }^{15}$ Id. The 2002 ISAAA study had this to say regarding the rapid adoption of GMO crops: "If the global areas (conventional and transgenic) of these four principal GM crops are aggregated, the total area is 271 million has., of which between 21 and $22 \%$ is GM, up substantially from $19 \%$ in 2001." Also, "(t)o put 58.7 million has. into context, it is more than 5\% the total land area of China or the US or almost two and half times the land area of the United Kingdom." 
${ }^{16}$ Council for Biotechnology Information (CBI), at http://www.whybiotech.com/index.asp?id=2391 (Feb. $12,2003)$. Referencing the 2002 ISAAA study, and stating that "(w)hile the lion's share of the global area planted to biotech crops is in the United States - which accounted for 66 percent of global plantings - the adoption of biotech crops in 2002 was more than twice as fast in developing countries as it was in developed countries. Growth in biotech plantings in developing countries of the South grew 19 percent in 2002 compared to a 9 percent growth rate in the industrial countries of the North, according to the ISAAA. In 2002, about 27 percent of the biotech acreage was planted in the developing world - a figure that has grown consistently from 14 percent in 1997, 16 percent in 1998, 18 percent in 1999, 24 percent in 2000 and 26 percent in 2001." See also Clive James, ISAAA, Global Status of Commercialized Transgenic Crops: 2002, ISAAA Briefs No. 27: Preview at 3, 5 (Jan. 16, 2003).

${ }^{17}$ Sarah M. Dunn, Comment, From Flav'r Sav'r to Environmental Saver? Biotechnology and the Future of Agriculture, International Trade, and the Environment, 9 Colo. J. Int'l. Envtl. L. \& Pol'y. 145, 145-50 (1998) (recounting the contributions of 1970 Nobel Prize winner Norman Borlaug and others to the "green revolution". Borlaug was responsible for developing new strains of wheat in Mexico, allowing production there to quadruple in 20 years. See Kingsley R. Stern, Introductory Plant Biology 247 (4th ed. 1988)).

${ }^{18}$ The FAO has deemed poverty to be the number one factor contributing to the global food crisis. Lack of access to food from poverty often stems from wars, distribution problems, price competition, drought, and environmental degradation produced by unsustainable agricultural practices. See Food and Agriculture Organization of the United Nations, Food Insecurity: When People Live With Hunger and Fear Starvation (4th ed. 2002), available at http://www.fao.org/DOCREP/005/Y7352E/Y7352E00.HTM (Jan. 23, 2003)

${ }^{19}$ Of Frankenfoods and Golden Rice: Risks, Rewards, and Realities of Genetically Modified Foods, (Frederick H. Buttel \& Robert M. Goodman eds., 2001) (diverse viewpoints from a wide array of thinkers on the GM debate, brought together from a Wisconsin Academy of Sciences, Arts and Letters public forum on the subject).

${ }^{20}$ Margaret Rosso Grossman, American Law in a Time of Global Interdependence: U.S. National Reports to the XVIth International Congress of Comparative Law: Section II: Biotechnology, Property Rights and the Environment, 50 Am. J. Comp. L. 215, 218 (Fall 2002). Grossman refers to "first generation" crops as those offering insect tolerance or herbicide resistance as a means to improve efficiency and cost savings in production methods as well as to reduce the need for multiple herbicide applications. "Second generation" crops are those promising nutritional benefits and increased yields.

${ }^{21}$ Pew Initiative on Food and Biotechnology, Harvest on the Horizon: Future Uses of Agricultural Biotechnology (2001) at 32-44, at http://pewagbiotech.org/ research/harvest/ (Jan. 23, 2003) (profiling genetically engineered products currently in development with added nutritional benefits). See also Council for Biotechnology Information (CBI), at http://www.whybiotech.com/index.asp?id=1973 (Feb. 12, 2003), containing a large list of products currently in development with added nutritional benefits such as soybeans with the allergen inducing gene disabled.

${ }^{22}$ Madeline Nash, Grains of Hope: Genetically Engineered Crops Could Revolutionize Farming. Protesters Fear They Could Also Destroy The Ecosystem. You Decide, Time, July 31, 2000, at 39.

${ }^{23}$ Food and Agriculture Organization of the United Nations, Food Insecurity: When People Live With Hunger and Fear Starvation (4th ed. 2002) at 8, available at http://www.fao.org/DOCREP/005/Y7352E/Y7352E00.HTM (Feb. 12, 2003). The FAO estimates that between 1998 and 2000, 799 million people in the developing world were undernourished. Golden rice is especially promising because it features as a staple in the diet of half the world's population. See also Council for Biotechnology Information (CBI), at http://www.whybiotech.com/index.asp?id=1973 (Feb. 12, 2003).

${ }^{24}$ Council for Biotechnology Information (CBI), at http://www.whybiotech.com/index.asp?id=1973 (Feb. 12 , 2003). 
${ }^{25}$ See Smith, supra note 2, at 34-5.

${ }^{26}$ WHO Answers Questions About Biotechnology Foods, Fact Sheet Released by the U.S. Department of State, October 15, 2002, available at http://usinfo.state.gov/topical/global/biotech/02101801.htm (Feb. 12, 2003) (responding to the question of are GM foods safe by stating: "GM foods currently available on the international market have passed risk assessments and are not likely to present risks for human health. In addition, no effects on human health have been shown as a result of the consumption of such foods by the general population in the countries where they have been approved."). See also Royal Society of London, et al., supra note 9, at 15, stating that "no human health problems associated specifically with the ingestion of transgenic crops or their products have been identified."

${ }^{27}$ See Leggio, supra note 8, at 903-4. For a description of "wide crosses" see supra note 9.

${ }^{28}$ See Smith, supra note 2, at 3, 61. Experts testified before the House committee that scientific data from the Center for Disease Control corroborated claims that organic foods were more likely to contain dangerous mycotoxins and bacteria known to be dangerous to human health than were their genetically engineered counterparts. See also Leggio, supra note 8, at 901. While no independent government testing is legally required in the U.S., company testing of GMOs for possible toxic or allergic properties must be done to comply with the FDA Pre-Market Biotechnology Notice (PBN) (infra Part II). In the E.U., GMOs are legally required to undergo such testing under Directive 2001/18/EC (infra Part II). Such tests are not required of foods produced by traditional cross-breeding techniques.

${ }^{29}$ The Flavr-Savr tomato, developed by Calgene, was the first GMO to receive U.S. Government approval for food use in May of 1994. See Dunn, supra note 17, at 146. While no one can predict the future, requiring long-term studies of any product with the potential to have adverse long-term effects is an impracticable procedure. In keeping with this view, the Codex Alimentarius Commission, a joint body of the FAO and WHO charged with the task of developing international standards in the field of biotechnology risk assessment, is considering the adoption of a "substantial equivalence" test as a starting point for safety assessments. "This approach is based on the principal that the safety of foods derived from new plant varieties, including recombinant-DNA plants is assessed relative to the conventional counterpart having a history of safe use, taking into account both intended and unintended effects. Rather than trying to identify every hazard associated with a particular food, the intention is to identify new or altered hazards relative to the conventional counterpart." See Codex Alimentarius Commission, Joint FAO/WHO Food Standard Programme, Report of the Third Session of the Codex Ad Hoc Intergovernmental Task Force on Foods Derived from Biotechnology, at 47 (March 2002) available at ftp://ftp.fao.org/codex/alinorm03/A103_34e.pdf (February 1, 2003). See also Smith, supra note 2, at 52, on "substantial equivalence."

${ }^{30}$ A. Bryan Endres, 'GMO': Genetically Modified Organisms or Gigantic Monetary Obligation? The Liability Schemes for GMO Damage in the United States and the European Union, 22 Loy. L.A. Int'l \& Comp. L. Rev. 453-60 (2000) (detailing opposition fears to the dangers of GMOs).

${ }^{31}$ Mae-Wan Ho, Perils and Promises of Genetically Modified Foods, Prepared on behalf of Greenpeace International, November 1996, at 8, available at http://archive.greenpeace.org/ geneng/reports/food/food003.doc

${ }^{32}$ Amelia P. Nelson, Legal Liability in the Wake of StarLink TM: Who Pays in the End?, 7 Drake J. Agric. L. 241, 242, 254-5 (Spring 2002). The corn, called StarLink, was developed by Aventis Crop Science (which has since merged with Bayer Crop Science) and approved for use as animal feed. The corn contained a bacterial protein Cry9C that was not easily digested, similar to some allergens, and the FDA therefore withheld approval for human consumption until further testing could be done.

Commingling with corn approved for human consumption occurred due to the fact that growers and shippers did not quarantine the GM corn from the other varieties. The incident caused an international scare that threatened the agricultural corn market and forced Aventis to purchase the entire 2000 crop of 
StarLink at a cost of about $\$ 0.25$ over local prices per bushel. Dollar losses to Aventis stretched well into the tens of millions. See also D.L.Uchtmann, Starlink TM -- A Case Study of Agricultural Biotechnology Regulation, 7 Drake J. Agric. L. 159, 194 (Spring,2002). Lawsuits followed. See In re StarLink Corn Products Liability Litigation, 152 F. Supp. 2d 1378, 1379-80 (J.P.M.L. 2001). The Center for Disease Control's (CDC) found in June of 2001 that there was no evidence that biotech Starlink corn caused allergic reactions in those who consumed it. See American Council on Science and Health, Editorial, Scientists Point to Lessons Learned From StarLink Scare, June 15, 2001, available at http://www.acsh.org/press/releases/message061401.html (Feb. 13, 2003). Another allergen scare arose when Pioneer Hi-bred researchers were experimenting with adding a brazil nut gene to soybeans in order to improve the soybean's nutrient content. Allergen testing alerted the researchers that the new transgenic soybean would trigger the same allergic reaction as brazil nuts in susceptible consumers, and the company decided not to release the soybean for sale. See Food and Agriculture Organization of the United Nations, FAO Ethics Series No. 2, Genetically Modified Organisms, Consumers, Food Safety and the Environment (2001), available at http://www.fao.org/DOCREP/003/X9602E/x9602e06.htm\#TopOfPage (Feb. 14, 2003).

${ }^{33}$ See Nelson, supra note 32, at 242.

${ }^{34} I d$. at $251-4$.

${ }^{35}$ Marker genes are genes inserted into a seed to allow a company to identify its plants and offspring. In this way a company can know whether a given acreage is composed of GM seed. It is commonly used to protect intellectual property (IP) rights by indicating when a farmer is using the company's GM seeds without permission. While marker genes need not contain antibiotic resistance, in the GMO context antibiotic resistance genes are frequently used to identify those cells having undergone successful genetic alteration. Researchers often use bacteria such as $E$ coli as the host organism during the development of a gene construct. By inserting the antibiotic resistance genes (ampicillin, for example) into the $E$ coli gene construct, those cells that are able to grow and function in the presence of the bacteria can be identified as having successfully undergone genetic alteration, and can be subsequently developed into a GMO. The genetic marker allows the researcher to identify and select the small number of cells having undergone transformation, without having to include the dying, unaltered cells. See Deborah Reed, Environmental Risk Management Authority of New Zealand, Use of Antibiotic Resistance Marker Genes in Genetically Modified Organisms, at 19 (December 2000), available at http://www.ermanz.govt.nz/Publications/pdfs/ER-GI-01-1.pdf (March 25, 2003).

${ }^{36}$ See Royal Society of London, et al., supra note 9, at 15 . This need not be a cause for alarm, however, as the report notes that scientists can now remove these marker genes before a crop plant is developed for commercial use.

${ }^{37}$ While these risks have been acknowledged as possible to occur, putting the transfer of antibiotic resistance from GMOs in its relevant risk context is appropriate. As one expert has stated: "The risk of corrupting the usefulness of pharmaceutical antibiotics by having the currently used marker genes in crops is considerably below the risk posed by using clinically important antibiotics widely as prophylactic agents for humans or to enhance the growth of farm animals." These are arguably two practices of greater use and concern for developing antibiotic resistance. See Jennifer Thompson, Horizontal Transfer of DNA from GM crops to Bacteria and to Mammalian Cells, Report prepared for Joint FAO/WHO Expert Consultation on Foods Derived From Biotechnology, Topic 11: Gene Transfer: Mechanisms and Food Safety Risks, Biotech 00/13 at 7 (June 2000), available at ftp://ftp.fao.org/es/esn/food/Bio-13.pdf (February 1, 2003).

${ }^{38}$ George E.C. York, Note, Global Foods, Local Tastes and Biotechnology: The New Legal Architecture of International Agriculture Trade, 7 Colum. J. Eur. L. 423, 430-1 (Fall 2001).

${ }^{39} I d$. at 430.

${ }^{40}$ Id. See also Smith, supra note 2, at 61. 
${ }^{41}$ See York, supra note 38, at 431. See also CBI supra note 24, at http://www.whybiotech.com/index.asp?id=1125

${ }^{42} I d$.

${ }^{43}$ See Pew Initiative on Food and Biotechnology supra note 21, at 63-68.

${ }^{44}$ Id. at $64-5$.

${ }^{45}$ Id. at 66.

${ }^{46}$ See Murphy, supra note 7, at 56.

${ }^{47}$ It is important to remember that crop displacement by foreign species occurred with traditional crops, and that although research has shown traditional non-indigenous (foreign) crops to have caused severe ecological damage, no evidence currently shows similar damage as a result of GM crops. See Grossman, supra note 20, at 219

${ }^{48} I d$.

${ }^{49}$ Gene flow can occur between traditional species and GM species relatives, or "horizontally" between sexually unrelated organisms (different species) such as bacteria in the soil or animals that eat the crops. See Thompson, supra note 35 at 2, 9-10 (concluding that horizontal DNA transfer risks from GM foods are small, and regulatory efforts should focus on the safety of the individual proteins transferred by genetic engineering, rather than the process itself).

${ }^{50} I d$.

${ }^{51}$ David E. Ervin et al., Transgenic Crops: An Environmental Assessment 22 (Henry A. Wallace Center for Agricultural and Environmental Policy at Winrock International, Nov. 2000), available at http://www.winrock.org/general/Publications/Transgenic.pdf (Feb. 16, 2003).

${ }^{52} I d$. The authors note at 23 that there are many practices that can be undertaken to limit the possibility of unintended gene flow, such as "rotating crops, spatial isolation, harvesting crops before flowering, planting non-transgenic crops as pollen trap crops, and avoiding production of transgenic crops with available wild relatives."

${ }^{53}$ Id. at 23,24

${ }^{54}$ See Murphy supra note 7, at 59. See also Ervin et al., supra note 51, at 23-24, 31-32.

${ }^{55}$ Of particular relevance is a controversial study conducted at Cornell University in 1999 that claimed the pollen from Bt corn had the effect of killing monarch butterfly larvae in their neighboring breeding areas.

See Blaine Friedlander, Toxic Pollen From Genetically Modified Corn Kills Monarch Butterflies,

Researchers Find in Lab Tests, Cornell Chronicle, available at

http://www.news.cornell.edu/releases/May99/Butterflies.bpf.html. This study has since been discounted by later research. See USDA Agricultural Research Service, Butterflies and Bt Corn: Allowing Science to Guide Decisions, available at http://www.ars.usda.gov/sites/monarch/index.html (Feb. 16, 2003) (providing a wealth of further studies reaching the conclusion that Bt corn doesn't harm monarch butterflies). Of course, it should also be remembered that conventional farming pest removal practices such as crop dusting and insecticide applications have historically harmed beneficial insects as well. On how GMOs have helped to slow the use of such damaging practices, see Mark A. King, The Dilemma of Genetically Modified Products at Home and Abroad, 6 Drake J. Agric. L. 241, 242 (2001). 
${ }^{56} I d$.

57 The EPA has required refuge areas for GM corn and cotton engineered with Bt. "The strategy of the program focuses on the level of the PIP (plant-incorporated protectant, the term the EPA uses for GMOs containing chemicals that serve as a natural defense against pests) produced and the planting of refuges (areas set within or close to a field of the genetically modified crop where unmodified versions of the same crops are planted). By setting these crops close to each other, the refuge encourages the interbreeding of resistant and nonresistant insects, reducing the likelihood of pesticide-resistant offspring." See Environmental Protection Agency, EPA's Regulation of Biotechnology for use in Pest Management, May 2002 available at http://www.epa.gov/pesticides/biopesticides/reg_of_biotech/eparegofbiotech.htm (Feb. 16, 2003). Some seed companies require GM crop growers to plant a certain percentage of their land with conventional crops to prevent insect resistance. See Grossman, supra note 20, at 220.

${ }^{58}$ Brian Halweil, The Role of Biotechnology in Combating Poverty and Hunger in Developing Nations, Worldwatch Institute, Remarks Prepared for Testimony given before the Subcommittee on International Economic Policy, Export and Trade Promotion, Senate Committee on Foreign Relations, July 12, 2000 available at http://www.worldwatch.org/biotech/bhtest.html (Feb. 16, 2003). Developing world farmers could realize important efficiency gains from GMO varieties of chickpeas, groundnut and cassava, but development in these crops has not been readily commercialized because they are not generally farmed in the developed world.

${ }^{59}$ Julie Teel, Regulating Genetically Modified Products and Processes: An Overview of Approaches, 8 N.Y.U. Envtl. L.J. 649, 656 (2000). The danger is that as more plants acquire the added survival advantages of the GM genes, they will spread, covering land that was previously occupied by other nonGM varieties. These non-GM plant varieties, especially non-crop varieties that may contain important undiscovered medical properties, will be forced into obscurity or even extinction. A lack of access to these diverse plants would make the development of new scientific advances from their unique genetic properties at least more costly, and at worst, impossible.

${ }^{60}$ The necessity of maintaining and cultivating the benefits of biological and genetic diversity is recognized in many international agreements. Chief among these are the Convention on Biological Diversity, (5 June 1992), at http://www.biodiv.org/doc/legal/cbd-en.pdf (Jan. 23, 2003) (efforts aimed to reduce potential threats to biodiversity and ensure the safety of biotechnology); and the Cartegena Protocol on Biosafety to the Convention on Biological Diversity, (29 January 2000), at http://www.biodiv.org/doc/legal/cartagenaprotocol-en.pdf (Jan. 23, 2003) (setting forth a mechanism to facilitate the safe transfer, handling and use of GMOs). For the view that GMOs will do serious harm to biological diversity and food security, especially in the developing world, see Ho, supra note 30 , at 3, 4.

${ }^{61}$ The importance of which was recognized in the Convention Concerning the Protection of World Cultural and Natural Heritage, (21 November, 1972), at http://whc.unesco.org/archive/convtext.htm (Feb. 17, 2003).

${ }^{62}$ For an interesting look at understanding policy making decisions in environmental law when faced with competing values that defy traditional methods of objective quantification, see Cass R. Sunstein, Endogenous Preferences, Environmental Law, 22 J. Legal Stud. 217, 248-53 (1993).

${ }^{63}$ Foremost among these issues is the proper scope to be given to intellectual property rights for GMOs. This issue will be discussed more fully in Part III on regulation of GMOs.

${ }^{64}$ The organic food market illustrates the relationship between higher production costs and higher consumer prices. Although a portion of the elevated price of organic goods can be attributed to the premium that some consumers place on those products, a sizeable portion stems from increased production costs. Having to continually rotate crops and harrow fields to fight pests without resorting to chemical herbicides and pesticides generally leads to increased costs and lower yields when compared to conventional or GM farming methods. See Bruce Barcott, Seeds of Discord: Bruce Barcott on the Battle 
to Stop Genetically Modified Seeds From Overrunning Organic Farms, Legal Affairs 59, (January/February, 2003).

${ }^{65}$ Leonard P. Gianessi et al., National Center for Food and Agricultural Policy (NCFAP), Plant Biotechnology: Current and Potential Impact for Improving Pest Management in U.S. Agriculture- An Analysis of 40 Case Studies, Executive Summary at 1 (June 2002), available at http://www.ncfap.org/40CaseStudies/NCFAB\%20Exec\%20Sum.pdf (Feb. 17, 2003). The study looked at production costs of $8 \mathrm{GM}$ crop varieties in 2001 (insect resistant corn and cotton, herbicide resistant canola, corn, cotton and soybean, and virus resistant papaya and squash) and concluded that the GM varieties realized a net gain of $\$ 1.5$ billion (increase value of crop $+/$ - any change in grower costs). Also included in the study were 32 cultivars being developed and their potential impacts. Case studies of these 32 cultivars found that the GM varieties would produce a net benefit of $\$ 1$ billion. When added to the existing 8 varieties currently employed, the study found GM crops to comprise a combined value to U.S. agriculture of $\$ 2.5$ billion, based on increased yields and crop savings.

${ }^{66} I d$.

${ }^{67}$ Yousouf Ismael et al., The University of Reading, Biotechnology in Africa: The Adoption and Economic Impacts of Bt Cotton in the Makhathini Flats, Republic of South Africa, Paper Presented for AfricaBio Conference: Biotechnology Conference for Sub-Saharan Africa at 10-12 (26-27 September 2001), available at http://www.agbioworld.org/biotech_info/topics/agbiotech/africa.pdf (Feb. 17, 2003). The paper concludes by noting: "There would appear to be yield, cost and gross margin benefits for small holders of growing Bt cotton compared to the conventional alternatives, especially for the smallest producers- which has important implications for livelihoods. Moreover, there should be associated environmental and human health benefits."

${ }^{68} I d$ at 12 . The study notes, however, that a decision by GM seed companies to raise their prices could work to wipeout some of the gains currently achieved by GM farmers.

${ }^{69}$ See Halweil, supra note 57. Scientific studies are also casting shadows on the cost effectiveness of certain biotech crops. See Willie Vogt, Science Paper Issues Biotech Caution, Farm Progress, July 2001, at http://www.biotech-info.net/caution.html. (Feb. 18, 2003) (detailing findings of an Iowa State entomologist that the use of Bt corn in the Midwest has not decreased farmer's insecticide use while costing more per seed).

${ }^{70}$ Lizette Alvarez, Consumers in Europe Resist Gene Altered Foods, NY Times, Feb. 11, 2003, at http://www.nytimes.com/2003/02/11/international/europe/11FOOD.html?ex=1045972866\&ei=1\&en=2ba8 11d706eca947 (Feb. 17, 2003).

${ }^{71}$ Marc Victor, Note, Precaution or Protectionism? The Precautionary Principle, Genetically Modified Organisms, and Allowing Unfounded Fear to Undermine Free Trade, 14 Transnat'l Law. 295 (Spring 2001). The EU. has been the most prominent in taking a strict regulatory approach to GMOs, but other states have been inclined to follow their lead. Among those with strict regulatory risk assessment and labeling requirements for GMOs are Australia, New Zealand, South Korea, Japan, Indonesia, the Philippines, India, Norway and Saudi Arabia. See York, supra note 37, at 454; Teel, supra note 58, at 6823.

${ }^{72}$ The strict regulatory concerns regarding GMOs are best seen through the legislative approach taken by the European Union. The specific approach of the E.U. to regulating GMOs will be discussed in Part II. For examples, see Council Directive 90/220/EEC, 1990 O.J. (L 117), (23 April 1990) (setting forth procedures applicable prior to the release of GMOs in the E.U. environment); Commission Directive 97/35/EC, 1997 O.J. (L 169) (adapting Directive 90/220/EEC in the wake of technological changes); Council Directive 2001/18/EC, 2001 O.J. (L 106), (12 March 2001) (repealing Directive 90/220/EEC and regulating procedures applicable to the deliberate release of GMOs into the E.U.); Council Regulation 1139/98, 1998 O.J. (L 159), (26 May 1998) (concerning compulsory labeling requirements of foodstuffs 
containing GMOs); and Council Regulation 258/97, 1997 O.J. (L 43), (27 January 1997) (concerning community wide safety assessments of novel food and novel food ingredients, terms used to describe products produced by genetic engineering and containing GMOs). For a good discussion of E.U. action in regard to GMOs, including the April 1998 ban on approval of GM crops for use in Europe, see York, supra note 37 , at $443-454$.

${ }^{73}$ Elizabeth Becker, U.S. Delays Suing Europe Over Ban on Modified Food, NY Times, Feb. 5, 2003, available at

http://www.checkbiotech.org/root/index.cfm?fuseaction=news\&doc_id=4640\&start=1\&control=200\&page _start=1\&page_nr=101\&pg=1 (Feb. 17, 2003). The verbal assaults in the U.S./E.U. trade war over GMOs have been particularly damaging. Becker notes: "Robert B. Zoellick, the United States trade representative, had said that the administration would decide soon whether to sue the Europeans for what he called their "immoral" opposition to genetically modified food. He said that stand was leading to starvation in the developing world." See also BBC News, Famine and the GM debate, BBC News, November 12, 2002, at http://news.bbc.co.uk/2/low/africa/2459903.stm (discussing African nation's refusal to accept GM food aid in November 2002).

${ }^{74}$ The Washington Post, U.S. Challenges E.U.'s Biotech Food Standards, The Washington Post, August 26, 2001.

${ }^{75}$ Endres, supra note 30, at 457-61.

${ }^{76} I d$. at 458 .

${ }^{77}$ Barcott, supra note 64, at 61 ( January/February, 2003).

${ }^{78} I d$.

${ }^{79}$ Nelson, supra note 32, at 251-52, discussing commingling, mishandling, and genetic drift as ways by which GM crops contaminate non-GM crops. "Genetic drift is the intermixing of pollen by air or animal dring time of pollination." It could also take the form of GM seeds spread to non -GM land by animals or some other means.

${ }^{80}$ Barcott, supra note 64, at 59- 61. Canadian farmer Arnold Taylor relates his experience in seeing his organic, non-GMO canola crop drop from commanding a price of \$14-a-bushel to \$6-a-bushel upon finding a tiny presence of GM protein.

${ }^{81} I d$. The European Union requires any food found to contain as little as 1 percent GM material to carry a label alerting consumers to its presence. See also Council Regulation 1139/98, 1998 O.J. (L 159), (26 May 1998); Commission Regulation 49/2000, 2000 O.J. (L 6), (10 January 2000) (amending Council Regulation 258/97); and Council Directive 2001/18/EC, 2001 O.J. (L 106), Article 13 (12 March 2001) (repealing Directive 90/220/EEC and regulating procedures applicable to the deliberate release of GMOs into the E.U.).

${ }^{82}$ The world organic market is estimated at over $\$ 21$ billion. Barcott, supra note 64 , at 61 . Canada adopted a voluntary certification program in 1999 that based organic certification on the overall farming methods used, not the purity of their crops. In October of 2002, the U.S.D.A., acting pursuant to the Organic Food Production Act of 1990 (OFPA), 7 U.S.C. § 6501 (1990), established a National Organic Program, setting forth similar production based organic certification standards. See National Organic Program, 7 CFR $\S$ 205.105 .

${ }^{83}$ See Barcott, supra note 64, at 60. "Members of the Saskatchewan Organic Directorate, a farmer's trade group, filed a class-action lawsuit against Monsanto and Aventis (Bayer CropScience). The suit seeks asyet-unspecified damages for the loss of the organic canola market and asks for a court order to prevent Monsanto from introducing GM wheat in Saskatchewan." The farmers offer several theories to explain 
why the biotech companies should be held liable. These claims include negligence (for failing to ensure the GM seeds wouldn't contaminate non-GM farmland), nuisance (for interfering with the the farmer's use of their land), trespass (for the unwanted drift of GMOs onto their land) and strict liability (for allowing the escape of something likely to cause harm or damage). The farmers also seek to have GMOs regulated as a pollutant under Canada's environmental statutes. For more lawsuits directed at GMO developers or regulatory agencies in charge of GMO approvals, see Higginbotham v. Monsanto Co., amended complaint, count V, Case No. 1:99cv03337 (D.D.C.), P 199, information at http://www.centerforfoodsafety.org/LegalUpdateAug20001.html (Feb. 18, 2003) (alleging Monsanto, the biotech giant, conspired to fix prices on its GM seeds and failed to adequately test its seeds for human health and environmental safety); In re StarLink Corn Products Liability Litigation, 212 F. Supp. 2d 828, N.D.Ill, (2002) (trial on issues regarding co-mingling of corn not approved for human consumption with approved corn could go forward on farmers state law nuisance and negligence claims); and Alliance for Bio-Integrity v. Shalala, 116 F. Supp. 2d 166, 181 (D. D. C. 2000) (coalition suit to challenge a policy statement issued by defendant that genetically engineered foods were not harmful, as violative of a number of federal acts (APA, NEPA, FFDCA, RFRA). The suit failed on summary judgment for the defendant (September 29, 2000).

${ }^{84}$ Barcott, supra note 64 , at 62.

${ }^{85}$ Environmental Media Services, Reporters' Guide to Genetic Engineering in Agriculture: Liability, October 2000, at http://www.ems.org/biotech/liability_insurance.html (Feb. 18, 2003). As part of these "technology use agreements", biotech companies generally retain the right to inspect farmers' fields and test their crops to ensure farmers aren't engaging in prohibited activities (such as saving seeds from one season to the next or failing to plant adequate "buffer zones" to reduce the likelihood of GM drift). The consequences for a farmer found to be growing GM crops without a license can be severe. See Monsanto Canada Inc. v. Schmeiser, 2001 FCT 256 (Fed. Ct. Canada, 2001), (biotech corporation's successful action to recover from farmer for unauthorized use of their "Roundup Ready" GM seeds). See also Barcott, supra note 72 , at 62 . The farmer claimed the GM seed had contaminated his field the previous year without his knowledge. The trial court found that Schmeiser knew or should have known that he needed a license to continue to plant the seed, and awarded Monsanto $\$ 19,832$ in Canadian dollars (approximately $\$ 12,700$ U.S. ). The appeals court upheld the decision in September 2002, and Schmeiser has since appealed to the Canada's supreme court. The issue of IP rights will be discussed further in Part III.

${ }^{86}$ Environmental Media Services, supra note 82, giving examples of insurance industry reluctance to offer coverage for GMO harms. "The Swiss reinsurance company, Rueck, for instance, concluded in 1998 that there was no satisfactory way for it to evaluate the risks and thus offer appropriate coverage. In the winter 1999 edition of the insurance industry magazine Post, Cigna International Manager Maurice Pullen said that Cigna would "think twice" before providing coverage for GE products, given its experience with asbestos, PCBs and other products that generated significant liability for the company. NFU Mutual, the largest farm insurance company in the UK, has announced that it will not offer insurance to farmers against the loss of "GMO-free" status, the potential loss of crops or loss of value of farmland through crosspollination and genetic pollution."

${ }^{87}$ A number of insurers currently offer GMO insurance policies. See Dobson-McOmber Agency, Inc., at http://dmagency.com/lifescience.cfm (offering insurance plans focused on the life science industry); Horenberg Insurance Services, Inc., at http://www.insuranceservices.com/tech/index.htm (offering insurance for biotech companies). See also Seed and Crops Magazine, Lloyd's of London Will Insure NonGMO Grain, Seed and Crop Magazine, June-July 2000, at http://www.gjs.com/article_GMO.htm (Feb. 18, 2003).

${ }^{88}$ A study undertaken by the Joint Research Centre of the European Commission found there to be high costs in establishing an agricultural environment where GM, conventional, and organic crops can co-exist. See Anne-Katrin Bock, et al., European Commission Joint Research Centre, Scenarios for Co-Existence of Genetically Modified, Conventional, and Organic Crops in European Agriculture, at 127-8 (May 2002) ,available at http://www.jrc.cec.eu.int/download/gmcrops_coexistence.pdf (Feb. 19, 2003). 
${ }^{89}$ Responsibility and Liability Under International Law for Environmental Damage, Institut du Droit International, 37 I.L.M. 1473, Article 2 (Sept. 4, 1997) (setting forth the recommended standards of liability to be applied by states in remedying harms to the environment in varying contexts).

${ }^{90}$ York, supra note 38, at 434.

${ }^{91}$ Marsha Echols, Food Safety Regulation in the European Union and the United States: Different Cultures, Different Laws, 4 Colum. J. Eur. L. 525 (1998) (illuminating the role culture has played in shaping the differing regulatory approaches to GMOs in the E.U. and U.S.).

${ }^{92} I d$. at 526. "Americans have been more willing to accept new technologies, an attitude that supports business innovation and a flexible regulatory system supportive of changing technology but skeptical of some traditional production processes."

${ }^{93}$ York, supra note 38, at 436.

${ }^{94}$ United States Department of Agriculture, Agricultural Biotechnology: FAQs, at http://www.usda.gov/agencies/biotech/faq.html (Feb. 19, 2003)

${ }^{95}$ York, supra note 38 , at 435.

${ }^{96} I d$. at 434-43. See also Teel, supra note 59, at 661-67.

${ }^{97}$ Department of Health and Human Services (HHS), Food and Drug Administration (FDA), Statement of Policy: Foods Derived From New Plant Varieties, Docket No. 92N-0139, 57 Fed. Reg. 22984 (May 29, 1992). See York, supra note 38, at 435 citing Echols, supra note 91, at 534.

${ }^{98}$ This includes the Codex Alimentarius Commission's Ad Hoc Intergovernmental Task Force on Foods Derived From Biotechnology, the joint FAO/WHO body charged with developing international standards for biotechnology risk assessments applicable in the WTO context. See Codex Alimentarius Commission, supra note 29, at 48. See also York, supra note 38, at 435. York mentions the National Academy of Sciences, the National Research Council, and the Organization for Economic Co-operation and Development as other bodies that subscribe to the "substantial equivalence" principle.

${ }^{99}$ Grossman, supra note 20, at 223-7.

${ }^{100}$ Executive Office of the President, Office of Science and Technology, Coordinated Framework for Regulation of Biotechnology, 51 Fed. Reg. 23302 (1986) cited in Grossman, supra note 20, at 223.

${ }^{101}$ Grossman, supra note 20, at 224, citing USDA, APHIS, United States Regulatory Oversight in Biotechnology, at http://www.aphis.usda.gov/biotech/OECD/usregs.htm\#usdalaw (visited 11 Sept. 2001).

${ }^{102}$ Agricultural Risk Protection Act of 2000, Title IV--Plant Protection Act, Pub. L. No. 106-224, 114 Stat. 358 (2000), codified at 7 U.S.C $\S \S 7701-7772$ (detailing USDA authority over GM Crops). The Act replaces the previous acts governing USDA action in biotechnology: The Plant Pest Act, 7 U.S.C. $\$ \S 150$ aa150jj; and the Plant Quarantine Act, 7 U.S.C. §§ 151-164a, 166-67.

${ }^{103}$ United States Department of Agriculture (USDA), Agricultural Biotechnology: USDA's Role, at http://www.usda.gov/agencies/biotech/role.html (Feb. 19, 2003).

${ }^{104}$ Id. "Applicants ask APHIS for permission to allow field testing (environmental release). They provide information about the plant, including all new genes and gene products, their origin, the purpose of the test, how the test will be conducted, and specific precautions to be taken to prevent the escape of pollen, plants, or plant parts from the field test site. An APHIS scientific reviewer evaluates the possible environmental 
impacts of the proposed field test. The possible impact of new plant varieties on endangered or threatened species is considered. Non-target species, those not meant to be directly impacted by the new plant, are also taken into account. In an effort to streamline the permit process, most applicants can now use a simplified procedure in which they notify APHIS before they plan to move or field test a biotech crop. APHIS then has 30 days to review the notification prior to any testing. These field tests are still required to meet all the same safety standards as trials that are approved through the permit process."

${ }^{105}$ Nathan W. Eckley, Note, Reaping the Benefits of Agricultural Biotechnology Through Uniform Regulation, 35 J. Marshall L. Rev. 433, 437 (Spring 2002), citing 7 C.F.R. §§ 340-340.9 (2003). "Safe" includes the criteria that the plant not be classified as a "plant pest" (defined in the Plant Protection Act, 7 U.S.C. § 7702 at Sec. 403 (14)) or "noxious weed" ( 7 U.S.C. §7712).

${ }^{106} I d$., at 437, citing 7 C.F.R. $\S 340.3$. See also USDA, supra note 103. "Generally, before a genetically engineered crop can be produced on a wider scale and sold commercially, its creators must petition APHIS for a 'determination of non-regulated status,' which requires the submission of more information than a field test permit request. APHIS must be provided scientific details about the genetics of the plant, the nature and origin of the genetic material used, information about indirect effects on other plants, field test reports, and even information unfavorable to the petition." The substantial equivalence principle is a hallmark of APHIS determinations. "APHIS grants the petition only if it determines that the plant poses no significant risk to other plants in the environment and is as safe to use as more traditional varieties."

${ }^{107}$ USDA, supra note 103. Recently, APHIS has announced in the Federal Register that it is strengthening the permit conditions to field-test plants genetically engineered to produce pharmaceutical and industrial compounds. These conditions are currently soliciting public comment, and include requirements of buffer zones for GM crops containing pharmaceuticals, approvals of seed and equipment cleaning methods, dedicated processing machinery for GM crops, and training programs. See USDA Strengthens 2003 Permit Conditions for Field Testing Genetically Modified Plants, at http://www.aphis.usda.gov/lpa/news/2003/03/gepermits_brs.html (March 25, 2003). See also 68 FR 11337-01 (March 10, 2003).

${ }^{108}$ Toxic Substances Control Act (TSCA), 15 U.S.C $\$ \$ 2601-2692$ (regulating chemical substances including micro-organisms that may pose an unreasonable risk to health and the environment).

${ }^{109}$ Federal Insecticide, Fungicide, and Rodenticide Act (FIFRA), 7 U.S.C §§ 136-136y (1994) (EPA regulation of GM plants with pesticidal properties)

${ }^{110}$ Federal Food, Drug, and Cosmetic Act (FFDCA), 21 U.S.C. $\S \S 301,342,346 a, 348$ (1994) (EPA regulation of GM plants containing pesticide chemicals for dietary consumption).

${ }^{111}$ Grossman, supra note 20, at 224-25.

${ }^{112} I d$.

${ }^{113} I d$, citing 7 U.S.C. § 136a.

${ }^{114}$ Ved P. Nanda, Genetically Modified Food and International Law-The Biosafety Protocol and Regulations in Europe, 28 Denv. J. Int'l L. \& Pol'y 235, 244 (2000).

${ }^{115}$ Grossman, supra note 20, at 225, citing 21 U.S.C. $§ 346$ a.

${ }^{116} I d$. See also Fact Sheet Released by the U.S. Department of State, supra note 26.

${ }^{117}$ FFDCA, supra note $110, \S \S 342$ (adulterated food), 348 (food additives).

${ }^{118}$ FDA, supra note 97 , at 22988. 
${ }^{119}$ Id., at 22989. See also Larry Thompson, Are Bioengineered Foods Safe?, U.S. Food and Drug Administration, FDA Consumer (January-February 2000), at http://www.cfsan.fda.gov/ dms/fdbioeng.html (Feb. 20, 2003).

${ }^{120}$ Thompson, supra note 119.

${ }^{121}$ Stanley H. Abramson, \& J. Thomas Carrato, Crop Biotechnology: The Case for Product Stewardship, 20 Va. Envtl. L.J. 241, 250-53 (2001) citing FDA, Premarket Notice Concerning Bioengineered Foods, 66 Fed. Reg. 4706 (proposed January 18, 2001), (to be codified at 21 C.F.R. 192, 592). The proposed is not likely to be finalized until some time in 2003. See Center for Science in the Public Interest, Rule on Genetically Engineered Food Stalled at FDA, CSPI Newsroom (May 3, 2002), available at http://www.cspinet.org/new/gefoodspr_050302.html (Feb. 20, 2003).

${ }^{122} I d$. at 4720.

${ }^{123}$ Id. at 4723 . Consultations can be viewed at the FDA's Center for Food Safety and Applied Nutrition (CFSAN) website, http://www.cfsan.fda.gov/ lrd/biocon.html (Feb. 20, 2003).

${ }^{124}$ FDA, supra note 97, at 22988-91. The FDA has postmarket legal authority over foods that are not "generally recognized as safe" under FFDCA 21 U.S.C. §§ 342(a)(1), 348.

${ }^{125}$ Id. at 22991.

${ }^{126}$ Teel, supra note 59 , at 666 .

${ }^{127}$ International Dairy Foods Ass'n v. Amestoy, 92 F.3d. 67 (2d. Circ. (Vt.) Aug. 8, 1996) (successful effort by trade association to declare Vermont's recombinant bovine growth hormone (rBST) labeling law in violation of the $1^{\text {st }}$ Amendment). See also 6 V.S.A. $\$ 2754$ (ruled unconstitutional restriction on free speech).

${ }^{128}$ While this may seem odd given the extensive nutritional labeling requirements currently employed under U.S. law, the result in Vermont can be seen to rely in part on the proposed label's assumed effect of misleading consumers into thinking the rBST products posed a greater risk to their health. In the current politically charged environment consisting of extensive interest-group propaganda stating the health risks of rBST, (risks that have yet to be scientifically substantiated), mandatory labeling could be seen as affixing a "scarlet letter" on affected products.

${ }^{129}$ See supra notes 29,98 .

${ }^{130}$ John Charles Kunich, Mother Frankenstein, Doctor Nature, and the Environmental Law of Genetic Engineering, 74 S. Cal. L. Rev. 807, 823 (2001). For a further sampling, see also Grossman, supra note 20, at 227-27; Lynn R. Goldman, Preventing Pollution?: U.S. Toxic Chemicals and Pesticides Policies and Sustainable Development, 32 Envtl. L. Rep. 11018 (September 2002); Sophia Kolehmainen, Precaution Before Profits: An Overview of Issues in Genetically Engineered Food and Crops, 20 Va. Envtl. L.J. 267, 288 (2001). This list is hardly exhaustive.

${ }^{131}$ Kunich, supra note 130 , at 823 .

${ }^{132}$ Eckley, supra note 105, at 445.

${ }^{133}$ Kunich, supra note 130 , at 823.

${ }^{134}$ Eckley, supra note 105, at 445. 
${ }^{135}$ Kolehmainen, supra note 130, at 293.

${ }^{136}$ Kunich, supra note 130 , at 823 .

${ }^{137}$ Grossman, supra note 20, at 227.

${ }^{138}$ FDA, supra note 124.

${ }^{139}$ Endres, supra note 30 , at 481-82.

${ }^{140}$ Id.

${ }^{141}$ Grossman, supra note 20, at 227. From 239-247, Grossman discusses how states and municipalities have attempted to regulate GMOs. Aside from assigning liability to parties under state law, states and municipalities can use land use zoning restrictions, permits and notification requirements to regulate GMOs. See Cal. Food \& Agric. Code $\S \S 52851-52982$ (restricting use of cotton lands to particular varieties of cotton); and Monterey County Zoning Ordinance, title 21, § 21.64.140, at http://elib.cs.berkeley.edu/cgi-bin/display_page?page=239\&elib_id=2051\&format=gif (Jan. 23, 2003) (preventing the release of GM organisms in Monterey County).

Some state legislatures (Minnesota, for example) have attempted to place GMO grower liability secondary to manufacturer liability. Others (Maine) have attempted to impose civil penalties on growers who fail to comply with minimum cross-contamination safeguards. Still others (Nebraska) have attempted to make the licensing party (GM seed companies) liable for cross-pollination. Some (Massachusetts) have even sought to make developers of GMOs designed for use as food strictly liable for any damages they cause.

Grossman notes that some commentators feel such efforts may run afoul of the dormant commerce clause of the U.S. Constitution by "acting discriminatorily or extraterritorially or by imposing excessive burdens on interstate commerce. For more discussion of these issues, see David R. Moeller, State GMO Restrictions and the Dormant Commerce Clause, Agric. L. Update, Aug. 2001, at 2, available at http://www.flaginc.org/pubs/arts/GMOrestrict.pdf. (looking at possible Commerce Clause objections to State GMO laws).

${ }^{142}$ Id. These can include commerce clause objections to alleged state interference with trade.

143 “(A) genetically modified cultivar costs about US\$30 million to develop, to which regulatory costs can add a further US\$5 to 6 million." FAO Technical Consultation on Biological Risk Management in Food and Agriculture, Biological Risk Management in Food and Agriculture: Scope and Relevance, at 8, January 13-17, 2003, at ftp://ftp.fao.org/es/esn/food/tc_bangkok/tc_brm_03_2en.doc.

${ }^{144}$ The two major treaty systems impacting international protections for biotechnology are the WTO Agreement on Trade Related Aspects of Intellectual Property Rights (TRIPS), and the Union internationale pour la protection des obtentions végétales (UPOV). Both allow for national IP protection of new plant varieties (including GMOs) using a sui generis system. Sui generis is a term meaning "unique, or of its own kind." See Laurence R. Helfer, Intellectual Property Rights in Plant Varieties: An Overview with Options for National Governments, FAO legal papers online \#31, at 11 (July 2002), available at http://www.fao.org/Legal/Prs-OL/lpo31.pdf (Jan. 23, 2003). While the U.S. was not an original UPOV signatory, it did follow the UPOV sui generis model in developing its approach to the protection of plant breeder's rights under the Plant Variety Protection Act of 1970. The U.S. has since ratified the 1991 UPOV treaty revision, and is also a party to the TRIPS Agreement. James F. Ewing, Agricultural Biotechnology: Is the International Regulation of Transgenic Agricultural Plants for the Birds (and the Bees)?, 25 Suffolk Transnat'1 L. Rev. 617, 623-27 (Summer 2002). See also Murphy, supra note 7, at footnote 88 .

145 The Plant Patent Act of 1930 (PPA), 35 U.S.C. $\$ 1161-164$ (1994 \& Supp. IV 1998), gives patent rights to inventors of asexually reproduced cultivated plants. The Plant Variety Protection Act of 1970 (PVPA), 7 U.S.C. $\$ \S 2321-2582$ (1994), and its later amendments extend this protection to plants produced via 
modern genetic engineering techniques. Ewing, supra note 144, at 624-26. In Diamond v. Chakrabarty, 447 U.S. 303 (1980), the U.S. Supreme Court held that living things were capable of being patented. Ex parte Hibbard, 227 U.S.P.Q 443 (1985) later held that plants, seeds and tissues can be protected under general patent law as well as under specific plant protection legislation. Newly developed plant breeds are held to be patentable subject matter. J.E.M. Ag Supply, Inc. v. Pioneer Hi-Bred Intern., Inc., 122 S.Ct. 593, (U.S. Iowa, 2001), see __U.S.__, 122 S.Ct. 1600 (rehearing denied Apr 15, 2002). Inventors of new plants can choose IP protections other than patents to protect their inventions. Plant breeder's rights (PBR) allow the IP holder to prohibit other breeders from marketing or selling a protected plant, but not from conducting their own research or breeding efforts involving the protected plant. An inventor can apply for PBR protection under the U.S. PVPA by requesting a PBR certificate. See 1970 U.S.C.C.A.N. 5082. This lesser IP protection for a new plant variety is seen as allowing society more opportunity to benefit from new applications using the protected plant.

A corollary right to PBR's and patents is recognized in the "farmer's rights" provisions of the UPOV International Convention for the Protection of New Varieties of Plants, (Dec. 2, 1961), 815 U.N.T.S. 89. Farmer's rights are also required of parties to the International Undertaking on Plant Genetic Resources, FAO Resolution 8/83, U.N. FAO, 22d Sess., art. 1 at 2, U.N. Doc. C/83/REP (1983), at ftp://ext- ftp.fao.org/waicent/pub/cgrfa8/iu/iutextE.pdf (setting forth provisions of farmers rights and access to genetic resources) as modified by International Treaty on Plant Genetic Resources for Food and Agriculture , (3 November 2001), at http://www.fao.org/ag/cgrfa/itpgr.htm (Jan. 22, 2003) (revising FAO Resolution $8 / 83$ to bring it into compliance with the Convention on Biological Diversity). Farmer's rights under UPOV provide that farmer's can use seeds from crops grown in previous seasons, although they cannot sell these seeds to others. Klaus Bosselmann, Plants and Politics: The International Legal Regime Concerning Biotechnology and Biodiversity, 7 Colo. J. Int'l Envtl. L. \& Pol'y 111, 121-26 (1996). See also Ewing, supra note 144, at 623-26; Pioneer Hi-Bred International, Inc. v. J.E.M. Agricultural Supply, Inc. (Patentability of Seeds and Seed-Grown Plants Under the Townsend-Purnell Plant Patent Act and the Plant Variety Protection Act), 16 Berkeley Tech. L.J. 497 (2001) (exploring the limits of genetic seed intellectual property rights); Neil D. Hamilton, Legal Issues Shaping Society's Acceptance of Biotechnology and Genetically Modified Organisms, 6 Drake J. Agric. L. 81 (2001) (detailing farmers rights for saving and replanting seeds under the PVPA); and Jim Chen, Diversity and Deadlock: Transcending Conventional Wisdom on the Relationship Between Biological Diversity and Intellectual Property, 31 Envtl. L. Rep. 10625 (2001) (looking at possible farmer's rights protections in the U.S., such as under the crop exemption provision in $\S 113$ of the PVPA, as well as "trade secret" protection to protect developing world indigenous knowledge from "biopiracy"). Murphy, supra note 7, at footnote 88 describes how UPOV breeder's rights provisions may not protect individual genes within GM plant varieties from being further used in a similar variety or product (such as taking a GM rice gene and engineering it into another variety of rice). Such a step may be greater than the protection from "essentially derived" new varieties provided by UPOV Article 14(5). Companies wishing to protect the individually engineered genes in issue may be able to prohibit others from utilizing it in other applications only by patenting the gene itself. Whether the genes themselves can be patented is open to question. Murphy suggests that WTO TRIPS requirements for the protection of international intellectual property may be satisfied by compliance with the UPOV convention.

${ }^{146}$ In an effort to prevent farmers from saving seeds, GM developers have developed the capability to create non-pollinating crops. Such so-called "terminator" seeds are genetically engineered to grow for only one season before dying. While such technology raises ethical questions about farmer dependency on biotech companies for access to seeds, it could be used by seed companies to eliminate difficulties posed by genetic drift and cross-pollination. See Nelson, supra note 32, at 265.

${ }^{147}$ Barcott, supra note 64 , at 62.

${ }^{148}$ David R. Moeller, Farmers and GMOs: An Overview of Liability Issues, Farmers' Legal Action Rep., 2000/5, at 3-5, available at http://www.flaginc.org/pubs/arts/GMOthreats.pdf.

${ }^{149}$ John P. Mandler and Kristen R. Eads, Liability Exposure to Seed Companies from Adventitious GMO Pollination Due to Pollen Drift Resulting in Cross Pollination or Outcrossing, at 21 (January 26, 2000), at 
http://www.faegre.com/downloads/gmo.doc (Feb. 21, 2003), citing The Uniform Commercial Code ("UCC"), §§ 2-316 and 2-719.

${ }^{150} I d$.

${ }^{151} I d$.

${ }^{152}$ Barcott, supra note 64, at 62.

${ }^{153} I d$., drawing on the observations of E. Ann Clark, an agricultural teacher at the University of Guelph. Unless a plaintiff were to join the government as a defendant in a tort claim alleging the regulatory standards that were set regarding GMO planting were negligent or otherwise lawfully inadequate, a company would likely be able to rely on compliance with applicable standards of care as a defense to various tort claims. Most current government liability standards allow a GMO producer to escape liability if they have complied with all applicable requirements. However, using the property analysis in Schmeiser may lead to consideration of a more strict liability standard than the fault or joint and several liability standards currently favored. These standards are explored more fully later in Part II.

${ }^{154}$ For an in-depth discussion of how various tort theories of recovery (trespass, negligence, public and private nuisance, breach of contract, product liability and strict liability) fare in various GMO harm scenarios, see Richard A. Repp, Biotech Pollution: Assessing Liability for Genetically Modified Crop Production and Genetic Drift, 36 Idaho L. Rev. 585 (2000); Endres, supra note 30; Grossman, supra note 20; and Nelson, supra note 32; Moeller, supra note 148.

${ }^{155}$ Grossman, supra note 20, at 228-29. This harm could be environmental, economic, or health related.

${ }^{156}$ This could include, for example, a processing establishment that failed to properly segregate GM seeds from conventional seeds when under an obligation to do so.

${ }^{157}$ Grossman, supra note 20, at 228-229. This can be seen in the inability of claimants against Aventis in the StarLink corn fiasco to prove that the corn caused their allergic reactions. In re StarLink, supra note 7.

${ }^{158}$ Nelson, supra note 32, at 258.

${ }^{159} I d$.

${ }^{160}$ Repp, supra note 153, at 600. See also Restatement (Second) of Torts, §§ 520, 821B, 821D (1965) (on negligence, trespass, and other common law recovery theories)

${ }^{161}$ Martin v. Reynolds Metals Co., 342 P.2d 790 (Or. 1959), cited in Repp, supra note 153, at 601. Drift from the aerial pesticide applications, such as crop dusting, have constituted a trespass. Mandler and Eads, supra note 149, at 10, citing Alm v. Johnson, 275 P.2d 959 (Idaho 1954) (aerial application of pesticide unreasonably interfered with plaintiff's enjoyment of his property).

${ }^{162}$ Some states regard invasion of plaintiff's property by particulates to be a nuisance, rather than a trespass. This visible, invisible distinction has been abolished in some jurisdictions. See Repp, supra note 153 , at 601 .

${ }^{163}$ Genetic marker technology could be used to identify crop ownership, much in the way that GMO companies police their IP rights.

${ }^{164}$ See supra, Part II, on economic harms of GMO use.

${ }^{165}$ Grossman, supra note 20, at 230. 
${ }^{166} \mathrm{Id}$.

${ }^{167}$ Repp, supra note 153 , at 606.

${ }^{168}$ Endres, supra note 30, at 491. In order for a private individual to proceed with a public nuisance suit, they must demonstrate an injury special and distinct from the harm suffered by the general public.

${ }^{169}$ Restatement (Second) of Torts, $§ 821 \mathrm{~B}$.

${ }^{170}$ Grossman, supra note 20, at 232, citing Higginbotham v. Monsanto Co., amended complaint, count V, Case No. 1:99cv03337 (D.D.C.), P 199, information at http://www.centerforfoodsafety.org/LegalUpdateAug20001.html (alleging Monsanto, the biotech giant, conspired to fix prices on its GM seeds and failed to adequately test its seeds for human health and environmental safety).

${ }^{171} I d$.

${ }^{172} I d$.

${ }^{173}$ Grossman, supra note 20, at 235. See also Repp, supra note 153, at 593.

${ }^{174}$ Endres, supra note 30, at 492.

${ }^{175}$ This could take the form of substantial loss of biodiversity, destruction of crucial ecosystem components (beneficial insects, soil bacterium), or any number of other asserted environmental hazards of GMO use. See supra, Part II, on environmental harms of GMOs.

${ }^{176}$ The elements needed to establish such compliance would likely include evidence that the company had properly submitted to the PBN requirements, the operator had enacted APHIS suggested buffer zones and handling procedures, and that efforts to reduce cross-pollination in line with or exceeding EPA rules such as GMO maximum land percentage requirements.

${ }^{177}$ Restatement (Second) of Torts, $§ 821 \mathrm{C}$.

${ }^{178}$ Endres, supra note 30, at 492.

${ }^{179}$ Endres, supra note30, at 493.

${ }^{180}$ Grossman, supra note 20, at 233-34. See also Bormann v. Board of Supervisors, 584 N.W.2d 309 (Iowa 1998), cert. denied sub nom. Girres v. Bormann, 525 U.S. 1172 (1999) (striking down IA "right to farm" statute as unconstitutional).

${ }^{181} I d$.

${ }^{182}$ Repp, supra note $153,607-13$.

${ }^{183}$ Grossman, supra note 20, at 233.

${ }^{184} I d$.

${ }^{185}$ Id. at $234-35$.

${ }^{186}$ Restatement (Second) of Torts $§ 284$.

${ }^{187}$ Repp, supra note 153, at 614. See also Endres, supra note 30, at 483. 
${ }^{188}$ More concrete proof of knowledge could be shown where scientific research and tests (either conducted by the defendant or known to them) show that such harm is likely to occur.

${ }^{189}$ Grossman, supra note 20, at 236-37.

${ }^{190} \mathrm{Id}$.

${ }^{191}$ Genetic marker technology or expert scientific testimony could provide the basis of a causal relationship.

${ }^{192}$ Grossman, supra note 20, at 237.

${ }^{193}$ Nelson, supra note 32, at 263.

${ }^{194}$ Id., citing Restatement (Third) of Torts: Products Liability $§ 1$ (1998). A product can be defective in design, or because of inadequate instructions or warnings.

${ }^{195}$ Grossman, supra note 20, at 237.

${ }^{196}$ Nelson, supra note 32, at 264.

${ }^{197}$ Grossman, supra note 20, at 239. "Proof that the GM product is defective in design or manufacture may be difficult for the plaintiff, however, and some products of biotechnology are exempt from strict products liability for defects in design."

${ }^{198}$ Endres, supra note 30, at 488, citing W. Page Keeton, Prosser and Keeton on Torts $164-65$ ( $5^{\text {th }}$ ed. 1984). See also Restatement (Second) of Torts $§ 520$ (a)-(f), listing 6 factors to consider in determining whether an activity is "abnormally dangerous," including commonality of usage and inappropriateness of the activity to the place where it is carried on.

199 James, supra note 13.

${ }^{200}$ Grossman, supra note 29 , at 238.

${ }^{201}$ Endres, supra note 30, at 489-90, citing Rylands v. Fletcher, [1861-1873] All E.R. Rep. 1 (1866) (Ex. Ch.) and Gotreaux v. Gary, 94 So. 2d 293 (La. 1957).

${ }^{202}$ Grossman, supra note 29 , at 238.

${ }^{203}$ Endres, supra note 30, at 490, citing Gotreaux.

${ }^{204}$ Langan v. Valicopters, Inc., 567 P. 2d 218 (Wash. 1977) (organic farmer's action to recover from neighbor for damages resulting from crop dusting on strict liability, wanton misconduct, and statutory violation grounds).

${ }^{205}$ Endres, supra note 30, at 490, citing Gotreaux.

${ }^{206}$ Some jurisdictions refuse to apply strict liability when the harmful thing is a "living organism." See Nelson, supra note 29, at 261-62.

${ }^{207}$ Grossman, supra note 29, at 238, citing Endres' reliance on Rylands, supra note 201.

${ }^{208}$ Endres, supra note 30, at 491, citing George P. Fletcher, Fairness and Utility in Tort Theory, 85 Harv. L. Rev. 537, 547-48 (1972) (qualifying the concept of nonreciprocal risk as especially relevant in justifying 
strict liability). A nonreciprocal risk is one created by the defendant that exceeds those to which he is reciprocally subject. A defendant may have a strict liability defense in the event the plaintiff is engaged in an unusually sensitive activity. A court could arguably include an organic farmer in this category.

${ }^{209}$ York, supra note 38, at 443.

${ }^{210} I d$. at 445-446. York notes the general characterization of Europeans as preferring traditional food practices as safer and closer to nature. Historical distrust of biotechnology is described as rooted in consumer distrust following the inability of the E.U. regulatory system to prevent such disasters as mad cow and foot and mouth disease, and dioxin-contaminated chicken. The dark shadow of Nazi genetic testing on humans may also play a role in the Europeans' distrust of genetic engineering techniques.

${ }^{211} I d$. at 443.

${ }^{212}$ The precautionary principle is acknowledged as having originated in the context of 1970's German environmental law, and has since been enshrined in numerous environmental treaties including: (1) paragraph 6 of the Preamble of the Montreal Protocol on Substances that Deplete the Ozone Layer (as amended in 1990); (2) Preamble of the U.N. Convention on Biological Diversity (1992); (3) Principle 15 of the Rio Declaration on Environment and Development (1992); (4) Article 3(3) of the U.N. Framework Convention on Climate Change (1992); (5) Article 3(2) of the Convention for the Protection of the Marine Environment of the Baltic Sea (1992); and (6) paragraph 4 of the Preamble, and Articles 10(6) and 11(8) of the Cartegena Protocol on Biosafety (2000). Id. at 444, footnote 122. The precautionary principle, as well as the polluter-pays principle, has even found its way into Article 174(2) of the Treaty Establishing the European Community (EC Treaty). European Union, Consolidated Versions of the Treaty on European Union and of the Treaty Establishing the European Community (2002), 2002/C 325/01, at C 325/107-8, available at $\mathrm{http}: / /$ europa.eu.int/eur-lex/en/dat/2002/c_325/c_32520021224en00010184.pdf (Feb. 25, 2003) (incorporating the Treaty of Nice signed on 26 February 2001).

${ }^{213} I d$. at 443.

${ }^{214}$ Application of the precautionary approach to risk assessment has been found not "scientifically based," in contravention of WTO trading rules in certain instances. WTO Dispute Panel, European Communities Measures Concerning Meat and Meat Products (Hormones), Aug. 18, 1997, WT/DS26/R/USA. The U.S. Trade Representative (U.S.T.R.) is currently being pressed to institute a similar suit to the "Beef Hormones" case against the E.U. for their policies in regards to GMOs. While many believe the U.S. would likely win such a case, the E.U. continued to maintain their ban on hormone treated beef after the WTO's 1997 ruling that such a ban was prohibited. The E.U. has urged the U.S.T.R. not to bring formal WTO complaints while the E.U. is still in the process of promulgating their directive regarding civil liability for GMO environmental damage. Elizabeth Becker, U.S. Delays Suing Europe Over Ban on Modified Food, NY Times, Feb. 5, 2003, available at

http://www.checkbiotech.org/root/index.cfm?fuseaction=news\&doc_id=4640\&start=1\&control=200\&page _start=1\&page_nr=101\&pg=1 (Feb. 17, 2003).

For current E.U. legislative proposals regarding environmental liability for damages from GMOs, see Commission of the EC, White Paper on Environmental Liability 26- 27, COM(2000)66 final (9 Feb. 2000) (proposal outlining the European Commission's recommendations for the establishment of an E.U. environmental liability framework); and Proposal for a Directive of the European Parliament and of the Council on Environmental Liability with Regard to the Prevention and Remedying of Environmental Damage, COM(2002) 17 final - 2002/0021 (COD); and Opinion of the Economic and Social Committee on the Proposal for a Directive of the European Parliament and of the Council on Environmental Liability with Regard to the Prevention and Remedying of Environmental Damage (COM(2002) 17 final 2002/0021 (COD)) Official Journal C 241, 07/10/2002 P. 0162 - 0167, available at http://europa.eu.int/eur-lex/pri/en/oj/dat/2002/c_241/c_24120021007en01620167.pdf (Jan. 23, 2003) (the ECSC review of the Council and Parliament's proposed liability directive, with suggestions for improvements). 
For a broader discussion of the precautionary principle and its effects on trade, see Vern R. Walker, Consistent Levels of Protection in International Trade Disputes: Using Risk Perception Research to Justify Different Levels of Acceptable Risk, 31 Envtl. L. Rep. 11317 (2001) (cutting through the quagmire of the precautionary principle and how it can be altered to embrace a more scientific mode of risk assessment without altering the accepted level of risk); Marc Victor, Note, Precaution or Protectionism? The Precautionary Principle, Genetically Modified Organisms, and Allowing Unfounded Fear to Undermine Free Trade, 14 Transnat'l Law. 295 (Spring 2001) (how the E.U. is using the precautionary principle to protect and appease vociferous special interest farmers); Deborah Katz, The Mismatch Between the Biosafety Protocol and the Precautionary Principle, 13 Geo. Int'l Envtl. L. Rev. 949 (2001) (providing other interpretations of the precautionary principle which may prove more harmonious, such as that in the OSPAR Convention); Jonathan H. Adler, More Sorry Than Safe: Assessing the Precautionary Principle and the Proposed International Biosafety Protocol, 35 Tex. Int'l L.J. 173 (2000) (detailing why habitat loss is inevitable and should not provide a basis for the precautionary principle).

${ }^{215}$ In February 2000, the European Commission attempted to clarify its understanding of the precautionary principle by setting forth applicable criteria to be utilized in its application. The communication states that the principle should not be applied on a discriminatory basis or so as to constitute a disguised restriction on trade. Measures should be proportionate to the chosen level of protection and should be mindful of the costs of action or inaction. New scientific data should subject measures to review to insure that accurate risk assessment. Measures may also assign responsibilities and burdens of proof requiring parties to produce the necessary evidence for a comprehensive risk assessment. York, supra note 38, at 444, citing the Communication from the Commission on the Precautionary Principle, Commission of the European Communities, COM (2000), February 2, 2000, at 7.

There are many commentators who believe that the precautionary principle can be applied in "scientifically" to a given level of risk so as not to constitute a disguised and arbitrary trade barrier. See Katz, supra note 214; Walker, supra note 214; David G.Victor, The Sanitary and Phytosanitary Agreement of the World Trade Organization: An Assessment After Five Years, 32 N.Y.U. J. Int'l L. \& Pol. 865 (2000) (assessing the effectiveness of the SPS agreement and possible clarifications to avoid disputes such as the application of the "precautionary principle"); and Stephen Charest, Bayesian Approaches to the Precautionary Principle, 12 Duke Envtl. L. \& Pol'y F. 265 (Spring 2002) (exploring how Bayes' Theorem's ability to combine a prior belief about a risk with new scientific information to guide rational decision making in cases of true uncertainty makes it more appropriate for risk assessment under the precautionary principle than classical hypothesis testing scientific approaches to risk assessment. Charest describes how the transparency and falsifiability of a Bayesian approach make it more appealing for risk assessment in political spheres such as trade were accountability is important).

${ }^{216}$ Id. at 443. The characterization of foods produced through genetic engineering as "novel foods" finds its regulatory expression in Council Regulation 258/97, 1997 O.J. (L 43), (27 January 1997) at 2-3 (concerning community wide safety assessments of novel food and novel food ingredients) as modified by Commission Regulation 49/2000, 2000 O.J. (L 6), (10 January 2000) at 2-3 (amending Council Regulation 258/97 to permit a $1 \%$ threshold of adventitious presence of maize and soy GMOs in unlabeled foodstuffs). The GMO regulation in the E.U. is authorized under Articles 94 and 95 of the EC Treaty. European Union, supra note 212 , at C 325/69-70.

${ }^{217}$ Endres, supra note 30, at 463-67. The specific legislative process utilized in the E.U. varies with the provision of the relevant community treaty providing the authority for the legislation. Regulations and directives may require differing approval procedures in the relevant E.U. bodies (Council, Commission, Parliament) before final implementation. See European Union, supra note 212.

Law in the European union may be established in the courts of the E.U. as well as in its political organs. According to the official E.U. legal website, EUR-Lex, "Community law may take the following forms:

- $\quad$ Regulations which are directly applicable and binding in all EU Member States without the need for any national implementing legislation.

- Directives which bind Member States as to the objectives to be achieved within a certain timelimit while leaving the national authorities the choice of form and means to be used. Directives 
have to be implemented in national legislation in accordance with the procedures of the individual Member States.

- Decisions which are binding in all their aspects for those to whom they are addressed. Thus, decisions do not require national implementing legislation. A decision may be addressed to any or all Member States, to enterprises or to individuals.

- Recommendations and opinions which are not binding."

See EUR-Lex, E.U. Law - Definitions: Secondary Legislation, at http://europa.eu.int/eur-

lex/en/about/pap/process_and_players2.html (Feb. 25, 2003).

${ }^{219}$ Article 5 of the EC Treaty. European Union, supra note 212, at C 325/41-2.

${ }^{220}$ Council Directive 90/220/EEC, 1990 O.J. (L 117), (23 April 1990) (setting forth procedures applicable prior to the release of GMOs in the E.U. environment). For a thorough discussion of the rules and procedures governing release of GMOs for both research and marketing in theE.U., see Rod Hunter, \& Koen Muylle, European Community: Product Related Regulation and Liability, 29 Envtl. L. Rep. 10515, at 10531-43 (Sept. 1999) (discussing how traditional products liability law in the E.C. may apply to GMOs).

${ }^{221}$ Endres, supra note 30, at 467.

${ }^{222}$ Council Directive 2001/18/EC, 2001 O.J. (L 106), (12 March 2001) (repealing Directive 90/220/EEC and regulating procedures applicable to the deliberate release of GMOs into the E.U., including labeling requirements). Article 2(2) of Directive 2001/18 defines GMOs to be "an organism, with the exception of human beings, in which the genetic material has been altered in a way that does not occur naturally by mating and/or natural recombination." The deadline for Member States to implement legislation to enforce the directive was October 17, 2002. That time has come and gone, with little discernible movement in the policies of the Member States, and the current GM ban approval moratorium continues.

${ }^{223}$ Endres, supra note 30, at 467.

${ }^{224}$ Teel, supra note 59, at 671, citing Council Regulation 258/97, arts. 1.2, 8.1, 1997 O.J. (L 43) 1, 2-3. Labeling of animal feed and seed is dealt with under Article 21 of Directive 2001/18. Current efforts are under discussion to harmonize labeling requirements of various GM products. See proposals in note 231, below. Council Regulation 178/2002, 2002 O.J. (L 031), (28 January 2002) establishes the European Food Safety Authority (ESFA). The ESFA is charged with carrying out independent scientific risk assessments of food and feed products.

${ }^{225}$ In the case of a GM food and non-food GMOs, the ESFA will act as the "one-door, one-key" portal for independent community risk assessments to be utilized by the Commission when it makes decisions. "The European Food Safety Authority will have a broad remit, allowing it to make scientific assessments of any matter which may have a direct of indirect effect on the safety of the food supply including matters in relation to animal health, animal welfare and plant health. This is essential so as to avoid repeating the failures of the past to identify emerging risks in one field that may have an impact on another as was the case with BSE which emerged initially only as an animal health problem. The Authority will also give scientific advice on non-food/feed GMOs and on nutrition in relation to Community legislation. It will therefore cover all stages of production and supply, from primary production, animal feed, right through to the supply of food to consumers." EFSA, Scope of European Food Safety Authority, at http://www.efsa.eu.int/scope_en.html (Feb. 25, 2003). See also Article 23 of Council Regulation 178/2002, supra note 224 , at L $31 / 13$.

${ }^{226}$ Endres, supra note 30, at 468.

${ }^{227}$ However, if subsequent to a GMO's approved release a Member State wishes to provisionally restrict the GMO because of justifiable reasons to consider it a risk to health or the environment, they may notify the Commission, and the pre-Member State consent procedures for release are repeated. Id. at 469. See also Article 22 of Directive 2001/18. 
${ }^{228} I d$.

${ }^{229} I d$.

${ }^{230}$ AgBios GM Database, at http://www.agbios.com/dbase.php (Feb. 25, 2003).

${ }^{231}$ Article 8 of Council Regulation 258/97, 1997 O.J. (L 43), (27 January 1997) (concerning community wide safety assessments of novel food and novel food ingredients and specific labeling requirements for novel foods). Council Regulation 1139/98, 1998 O.J. (L 159), (26 May 1998) as amended by Commission Regulation 49/2000/EC, 2000 O.J. (L 6), (10 January 2000) (requiring that products containing more than a $1 \%$ adventitious presence of GM maize or soya must be labeled). Other measures requiring labeling of GM products include Directive 2001/18/EC, supra note 219; Proposal for a Regulation of the European Parliament and of the Council Concerning Traceability and Labeling of Genetically Modified Organisms and Traceability of Food and Feed Products Produced From Genetically Modified Organisms and Amending Directive 2001/18/EC, (COM (2001) 182 final - 2001/0180(COD)), (25 July 2001); Amended Commission Proposal for a Regulation of the European Parliament and of the Council on Genetically Modified Food and Feed, (COM (2002) 559 final - 2001/0173(COD)), (8 October 2002); Commission Regulation 50/2000/EC, (10 January 2000) (concerning additives or flavorings that have been genetically modified or produced from GMOs); and Council Directive 98/95/EEC (on the labeling of GM seed varieties). The E.U. is also preparing legislation on transboundary movement and notification procedures in the Community. See Amended Proposal for a Regulation of the European Parliament and of the Council on the Transboundary Movement of Genetically Modified Organisms, (COM(2002) 578 final -- 2002/0046 (COD)), (16 October 2002). Liability for damage to the environment caused by GMOs is also the subject of current legislative efforts. See Commission of the EC, supra note 214, and subsequent proposals.

${ }^{232} I d$., at Articles 13 and 21 of Directive 2001/18.

${ }^{233}$ Id., at Regulation 49/2000/EC. The special approach to maize and soya reflects the fact that the time Regulation 258/97 was promulgated, GM maize and soya varieties had been approved for Community release and were recognized as safe, providing no basis for added labeling requirements under the safety assessment provisions of 258/97.

${ }^{234}$ Agreement on Trade Related Aspects of Intellectual Property Rights (TRIPS Agreement), (April 15, 1994), Article 27(1-3), Marrakesh Agreement Establishing the World Trade Organization (WTO Agreement), Annex 1C, at http://www.wto.org/english/docs_e/legal_e/27-trips.pdf (Jan.23, 2003) (outlining requirements for the protection of intellectual property rights, including plant breeders rights). Murphy, supra note 7, at 66-70, (footnote 88) notes that similar provisions to those contained in TRIPS are found in the Convention on the Grant of European Patents, (Oct. 5, 1973), 1065 U.N.T.S. 199.

"Interpretation of those provisions has been complex, with the European Patent Office issuing seemingly inconsistent opinions on the ability to patent genetically engineered plants and animals. See Darrel G. Dotson, Comment, The European Controversy Over Genetic-Engineering Patents, 19 Hous. J. Int'1 L. 919 (1997)." The European Patent Office issues patents enforceable throughout the E.U.

${ }^{235}$ Absent Community legislation, liability for GMO harms are dealt with by the legal systems in place in the various Member States. Endres, supra note 30, at 470-479 provides an overview of how the U.K., Austria, and Germany used their statutory, common law and civil law remedies to address liability and damage issues related to GMO harms under Directive 90/220. Directive 2001/18, the 2001 replacement of 90/220, continued 90/220's tradition of failing to include measures aimed at standardizing Community liability standards regarding GMOs. Private contractual provisions may also provide ways to allocate liability under individual Member State law, provided such provisions do not run counter to public policy or are unenforceable in light of violations of statutory or civil code provisions.

${ }^{236}$ Council Directive 85/374/EC, 1985 O.J. (L 210), (30 July 1985); Council Directive 1999/34/EC, 1999 O.J. (L 141), (6 April 1999). 
${ }^{237}$ Activities of the European Union: Summaries of Legislation - Consumers > Liability for Defective Products (Directive), at http://europa.eu.int/scadplus/leg/en/lvb/132012.htm (Feb. 25, 2003). This includes producers of primary agricultural products containing GMOs, such as meat, cereals, fruits and vegetables. See Article 5 of Directive 85/374/EC

${ }^{238} I d$. Article 3 of Directive 85/374/EC

${ }^{239}$ Id. Article 7 of Directive 85/374/EC

${ }^{240}$ This is demonstrated in the U.S. by the lack of any requirements for independent product research or labeling. Although those wishing to place a GM variety on the market must now notify U.S. authorities 60 days in advance, the Coordinated Framework's previous lack of even a notification procedure goes to show that the U.S. has always allowed the biotech industry to proceed with a great deal of self-regulation.

${ }^{241}$ Activities of the E.U., supra note 237, at 3 (8). See also Article 9(b) of Directive 89/374/EEC.

${ }^{242} I d$.

${ }^{243}$ See supra note 235 for Endres' relevant discussion.

${ }^{244}$ See Commission, and subsequent proposals, supra note 214, paragraph 2.

${ }^{245}$ Becker, supra note 214.

${ }^{246}$ Proposal for a Directive of the European Parliament and of the Council on Environmental Liability with Regard to the Prevention and Remedying of Environmental Damage, Preamble (3), COM(2002) 17 final 2002/0021 (COD).

${ }^{247} I d$. Articles 2 and 3 set forth the definitions of damage to the environment (including damage to biodiversity), as well as the scope of activities covered by the legislation. GMOs deliberately released into the environment in accordance with Directive 2001/18 are covered in Annex 1. Art. 3(1) subjects GMOs to liability for environmental damage, but Art. 3(2) excludes them from the directive's provisions on damage to biodiversity. In keeping with the "polluter pays" principle (Preamble (14)), operators shall bear the full costs of prevention (Art. 4) and restoration (Art. 5). Where multiple-party liability is in issue, Member States may adopt either joint and several or fault based liability schemes. Art. 11(1). Where an operator can establish the extent to which they are responsible for damage, they shall be liable only in relation to the damage they have caused. Art. 11(2).

${ }^{248} I d$. Article 18(1).

${ }^{249} I d$.

${ }^{250} I d$. Article 13.

${ }^{251} I d$. Article 2(1)(18)(a), (c).

${ }^{252} I d$. Article 3(6).

${ }^{253}$ Id. Article 14. Operators can include GMO developers, farmers, in effect anyone exercising control o over the handling or care of GMOs.

${ }^{254}$ Id. Articles 4, 5, 7 .

${ }^{255} I d$. Article 11. 
${ }^{256} I d$. Article 9. The exceptions for best available technology (BAT) and science, as well as legal compliance, do not apply to operators who have been found to act negligently. Art. 9(2).

${ }^{257}$ Id. Article 12.

${ }^{258} I d$. Article 8. Biodiversity is defined narrowly in Art. 2 (1)(1) to include only "natural habitats and species listed in Annex I to Directive 79/409/EEC, or in Annexes I, II and IV to Directive 92/43/EEC, or habitats and species, not covered by those Directives, for which areas of protection or conservation have been designated pursuant to the relevant national legislation on nature conservation."

${ }^{259}$ Id. Article 16.

${ }^{260} I d$. Article 19.

${ }^{261} I d$. Article 3(8). Private economic rights are of course not extinguished, and Article 11(3) allows national legal measures to provide for private economic compensation.

${ }^{262} I d$. Article 9(1)(c).

${ }^{263}$ Friends of the Earth Europe (FOEE), The European Commission Gives Industry a License to Pollute, FOEE, January 24, 2002, at http://www.foeeurope.org/press/24.01.02_The_European.htm.

${ }^{264}$ Proposal for a Directive, supra note 243, Annex II.

${ }^{265} I d$. Article 2(1)(1).

${ }^{266}$ Much literature exists on natural resource damage valuation. See C. Bishop and Robert E. Unsworth, Assessing Natural Resource Damages Using Environmental Amenities, 11 Ecological Econ. 35 (1994).

267 "Stewardship is the legal and ethical obligation to assess product risks and ensure that products are safe for the environment and for human consumption." Remarks of Thomas Carrato, Esq., Division Counsel, Monsanto Company, St. Louis, Missouri during a roundtable discussion of agricultural biotechnology at the Missouri Botanical Garden in St. Louis, Missouri on May 26, 1999. See Bernalyn D. McGaughey and Thomas P. Redick, Esq., Liability and Labeling of Genetically Modified Organisms, Council for Agricultural Science and Technology (CAST), February 6, 2000, at http://www.castscience.org/0002abab.htm.

${ }^{268}$ Benjamin J. Richardson, Mandating Environmental Liability Insurance, 12 Duke Envtl. L. \& Pol'y F. 293 (Spring 2002). Richardson sees claim ceilings and high deductibles as insurance tools to promote safe, ecologically careful industry practices by insureds. He also states that insuring against major, long term environmental risks could be overcome through the development of secondary markets for risk trading, allowing for "securitization" that promotes risk sharing between investors and insurers. Richardson explores the benefits of mandating environmental liability insurance, but cautions that such a practice must take account of the terms upon which insurance is made available, including insurer implementation of preventative measures, the methods of environmental risk appraisal, the type of damage (gradual or accidental) and basis covered (e.g., claims-made or occurrence).

${ }^{269}$ For "a comparative study of national regulations concerning biotechnology, including GMOs, exploring the possibility and desirability of harmonizing such regulations," see Food and Agriculture Organization of the United Nations, Commission on Genetic Resources for Food and Agriculture, "The Role of Law in Realising the Potential and Avoiding the Risks of Modern Biotechnology: Selected Issues of Relevance to Food and Agriculture" (Lyle Glowka, October 2002), available at ftp://ext-

ftp.fao.org/ag/cgrfa/BSP/bsp19e.pdf (Jan. 23, 2003). Glowka also examines the provisions of various international instruments that play a role in the regulation of biotechnology. 
${ }^{270}$ York, supra note 37, at 454-465.

${ }^{271} I d$ at 454 , footnote 188 . "There are currently over 30 ongoing multilateral discussions on biotechnology, including: Codex Ad Hoc Intergovernmental Task Force on Biotechnology; Codex Committee on Food Additives and Contaminants; Codex Committee on Residues of Veterinary Drugs in Foods; Codex Committee on General Principles; Codex Committee on Pesticide Residues; Codex Committee on Food Labeling; Codex Ad Hoc Intergovernmental Task Force on Animal Feeding; Codex Executive Committee; Codex Committee on Methods of Analysis and Sampling; FAO Ethics Panels; FAO Committee on Agriculture; Intergovernmental Committee on the Cartagena Protocol; Joint WHO-FAO Consultations; OECD Task Force on the Safety of Novel Foods and Feed; OECD Working Group on Harmonization of Regulatory Oversight of Biotechnology; OECD Ad Hoc Group on Food Safety; OECD Committee for Science and Technological Policy - Working Party on Biotechnology; OECD Committee on Agriculture; OECD Schemes for Seed Certification; Senior-Level Working Group Task Force; Transatlantic Economic Partnership; Transatlantic Business Dialogue; Transatlantic Consumer Dialogue; Transatlantic Environmental Dialogue; UN Council for Sustainable Development; UN Earth Summit; UN Conference on Trade and Development; US-EU Consultative Forum; WTO Agricultural Committee; WTO SPS Committee; WTO TRIPS Committee."

${ }^{272}$ General Agreement on Tariffs and Trade 1994, (Apr. 15, 1994), Marrakesh Agreement Establishing the World Trade Organization (WTO Agreement), 33 I.L.M. 1125 (agreement establishing the WTO); General Agreement on Tariffs and Trade, (Oct. 30, 1947), 55 U.N.T.S. 194 (setting forth permissible barriers to free trade); Understanding on Rules and Procedures Governing the Settlement of Disputes (DSU), Annex 2 of WTO Agreement, (April 15, 1994), at http://www.wto.org/english/docs_e/legal_e/28-dsu.pdf (creating the dispute settlement body (DSB) for the settlement of WTO member disputes).

${ }^{273}$ Agreement on the Application of Sanitary and Phytosanitary Measures (SPS Agreement), WTO Agreement, (April 15, 1994), at http://www.wto.org/english/docs_e/legal_e/15-sps.pdf (Jan. 23, 2003) (detailing acceptable trade measures regarding health and safety regulations); Agreement on Technical Barriers to Trade (TBT Agreement), WTO Agreement, (April 15, 1994) at http://www.wto.org/english/docs_e/legal_e/17-tbt.pdf (Feb. 19, 2003); Agreement on Agriculture, WTO Agreement, (April 15, 1994), at http://www.wto.org/english/docs_e/legal_e/14-ag.pdf (Jan. 23, 2003) (regulating international trade in agricultural products); Agreement on Trade Related Aspects of Intellectual Property Rights (TRIPS Agreement), (April 15, 1994), Article 27(1-3), WTO Agreement, Annex 1C, at http://www.wto.org/english/docs_e/legal_e/27-trips.pdf (Jan.23, 2003) (outlining requirements for the protection of intellectual property rights, including plant breeders rights). Understanding on Rules and Procedures Governing the Settlement of Disputes (DSU), Annex 2 of WTO Agreement, (April 15, 1994), at http://www.wto.org/english/docs_e/legal_e/28-dsu.pdf (creating the dispute settlement body (DSB) for the settlement of WTO member disputes).

${ }^{274}$ These agreements do not themselves set relevant international standards in technical or scientific matters. Instead, they provide guidelines for deciding whether a state's actions constitute an arbitrary or unjustifiable barrier to trade, in contravention of GATT rules. In interpreting the language of these instruments the Dispute Settlement Body (DSB) will be informed by relevant international treaties, as well as state practice, to determine whether the justifications proffered by a Member nation are acceptable under the terms of the side agreements. Bodies that the DSB may look to in the GM plant and plant product context are the Codex Alimentarius Commission (food and health standards), the International Plant Protection Convention (IPCC), the International Organization for Standardization (ISO), and the World Intellectual Property Organization (WIPO).

${ }^{275}$ General Agreement on Tariffs and Trade, (Oct. 30, 1947), Article XX (b), (d), (g), 55 U.N.T.S. 194, available at http://www.wto.org/english/docs_e/legal_e/gatt47_02_e.htm (setting forth permissible barriers to free trade). Article XX contains the general exceptions, with (b), (d) and (g) being most relevant to the environmental context. Article XX: General Exceptions 
Subject to the requirement that such measures are not applied in a manner which would constitute a means of arbitrary or unjustifiable discrimination between countries where the same conditions prevail, or a disguised restriction on international trade, nothing in this Agreement shall be construed to prevent the adoption or enforcement by any contracting party of measures:

...

(b) necessary to protect human, animal or plant life or health;

...

(d) necessary to secure compliance with laws or regulations which are not inconsistent with the provisions of this Agreement, including those relating to customs enforcement, the enforcement of monopolies operated under paragraph 4 of Article II and Article XVII, the protection of patents, trade marks and copyrights, and the prevention of deceptive practices;

...

(g) relating to the conservation of exhaustible natural resources if such measures are made effective in conjunction with restrictions on domestic production or consumption;

...

There are many WTO decisions that have helped to clarify the scope of these rules. The most prominent cases interpreting Article XX, SPS and TBT provisions are the Shrimp-Turtle Case (WTO Appellate Body, United State--Import Prohibition of Certain Shrimp and Shrimp Products, WT/DS58/AB/R (1998)) and the Beef Hormone Case (WTO Appellate Body, European Communities-Measures Concerning Meat and Meat Products (Hormones), Jan. 16, 1998, WT/DS26/AB/R, para. 41). A prominent "labeling" case under GATT prior to formation of the WTO is the Tuna-Dolphin Case (United States Restrictions on Imports of Tuna, Sept. 3, 1991, GATT B.I.S.D. (39 ${ }^{\text {th }}$ Supp.) at 155 (1993).

${ }^{276}$ It is generally due to the WTO's effectiveness in defeating the (arguably protectionist) policies of individual nations that have earned it the ill-will of protesters who see its pro-trade bias as undermining legitimate national environmental or health safety concerns. Although WTO sanctions can be an effective threat to encourage Member nation policy compliance, they are not foolproof. The E.U. has maintained their ban on hormone treated beef despite the 1997 WTO ruling that the embargo was illegal and authorizing the suspension of trade concessions from the U.S. and Canada in the amount \$125 million. The E.U. is currently attempting to get the trade concessions lifted. See Gary G. Yerkey, BNA's International Trade Reporter Europe, Agriculture: E.U. Plans Initiative at W.T.O. Seeking Removal of U.S. Sanctions in Beef Hormone Dispute, 19 ITR 2169, December 19, 2002.

${ }^{277}$ George Monbiot, Out of the Wreckage, The Guardian, February 25, 2003, at http://www.guardian.co.uk/comment/story/0,3604,902274,00.html. Monbiot describes the collapse of the effort to start a new round of WTO trade talks in Seattle in 1999, the relaunching of that effort in Quatar in 2001, and the political and environmental quagmire that currently exists among developing nations that want lower developed world agricultural subsidies and cheaper access to needed drugs, and developed countries like the U.S. and E.U. who are intent on not conceding as much. The global protests that dismantled the WTO talks in Seattle in '99 are anticipated to be equally strong at the ministerial meeting in Mexico in September 2003. Another repeat of Seattle could signify the end of the WTO. The increasing focus on regional trade agreements such as the Free Trade Area of the Americas (see Office of the United States Trade Representative, Second Draft Consolidated Text of the FTAA, at http://www.ustr.gov/regions/whemisphere/ftaa2002/secondtext.htm (March 1, 2003)) support the proposition that governments such as the United States are preparing for a WTO breakdown.

${ }^{278}$ Beef Hormones Case, supra notes 275, 276. For more on the difficulties of adapting the precautionary principle to reflect a sturdier grounding in the scientific method, see supra notes 214, 215.

${ }^{279}$ Elizabeth Becker, U.S. Contests Europe's Ban on Some Food, NY Times, May 14, 2003, at http://www.nytimes.com/2003/05/14/business/worldbusiness/14TRAD.html (May 14, 2003).

${ }^{280}$ Beef Hormones Case, supra notes 275, 276

${ }^{281}$ Murphy, supra note 7, at 83. 
${ }^{282}$ Codex Alimentarius Commission, Report of the Third Session of the Codex Ad Hoc Intergovernmental Task Force on Foods Derived from Biotechnology, March 4-8, 2002, at

$\mathrm{ftp} / / / \mathrm{ftp}$.fao.org/codex/alinorm03/A103_34e.pdf. The Codex Commission is a subsidiary body of the FAO and WHO that was created to provide internationally recognized standards on food commodities, hygiene and technology, pesticides, food additives, and other standards bearing on food and health.

${ }^{283}$ International Plant Protection Convention (IPPC) November 17, 1997, S. Treaty Doc. No. 106-23, 1997 WL 33143607

${ }^{284}$ Murphy, supra note 7, at 83-5. See also Codex, supra note 282, and IPPC, id.

${ }^{285}$ Codex, supra note 282 , at 43.

${ }^{286}$ SPS Agreement, supra note 273, Articles 3(3) and 5(7).

${ }^{287}$ See WHO, supra note 26.

${ }^{288}$ The outcome in the Beef Hormones Case supports this conclusion. It should be noted however, that scientifically unjustified trade restrictions in the E.U. will have profound effects on shaping the approach to biotechnology in both the developed and developing world. Less developed countries such as those in Africa, whose farmers may benefit the most from biotech food exports, will be less inclined to pursue use of the technology if E.U. markets remain closed to GM crops. The risk assessments of the E.U. have already resulted in developing countries (who lack the resources to conduct their own independent safety assessments) adopting similar no-GMO policies to keep out needed food aid. U.S. trade representative efforts to guilt E.U. political leaders into altering their no-GMO stance appear to be making headway. See Robert Zoellick, United States Trade Representative, Letters to the Editor: The Human Costs of Biotech Fear-Mongering, The Wall Street Journal, 24 January, 2003, at http://www.usembassy.org.uk/agri163.html (March 1, 2003).

${ }^{289}$ See supra notes 214,215 for authors who have proposed ways to square the precautionary principle and the Cartegena Protocol obligations with those of the WTO Agreements. The Protocol's provisions on advanced informed agreements (AIA), the notification and consent procedures required prior to the transport of GMOs intended to be released into the environment, have been criticized as likely to conflict with WTO rules against unnecessary barriers to trade. See Convention on Biological Diversity, (5 June 1992), Article 19, at http://www.biodiv.org/doc/legal/cbd-en.pdf (Jan. 23, 2003) (efforts aimed to reduce potential threats to biodiversity and ensure the safety of biotechnology).

${ }^{290}$ Murphy, supra note 7 , at 89.

${ }^{291}$ See Codex, supra note 282.

${ }^{292}$ Aside from greater familiarity with GMO disputes under national laws, parties to international agreements such as the Biodiversity Convention, along with bodies like the International Law Commission and the Instituit du Droit International are working to develop rules and procedures in the field of liability for damages from transboundary movements of GMOs. See Convention on Biological Diversity, (5 June 1992), at http://www.biodiv.org/doc/legal/cbd-en.pdf (Jan. 23, 2003) (efforts aimed to reduce potential threats to biodiversity and ensure the safety of biotechnology; Draft Articles on Prevention of Transboundary Harm from Hazardous Activities, (November 2001), at http://www.un.org/law/ilc/texts/prevention/preventionfra.htm (Jan. 23, 2003) (setting forth principles to be applied by states to prevent transboundary harm from hazardous activities not prohibited by international law); Responsibility and Liability Under International Law for Environmental Damage, Institut du Droit International, 37 I.L.M. 1473 (Sept. 4, 1997) (setting forth the recommended standards of liability to be applied by states in remedying harms to the environment in varying contexts); and also Council of Europe, 
Convention on Civil Liability for Damage Resulting from Activities Dangerous to the Environment, 32 I.L.M. 1228 (21 June 1993) (ensuring adequate compensation for damage to the environment resulting from dangerous activities in accordance with the "polluter pays" principle and applying strict liability). These efforts generally impose an obligation of strict liability on the polluting state for damage outside its jurisdiction caused by activities within its territory.

${ }^{293}$ By requiring planters of GMOs to encircle their GM crops with sterile GM varieties (so called "terminator seeds"), cross pollination could be contained without the fear of any farmers losing the ability to save seeds. Setting maximum terminator seed contract percentages under national law could also be a way to guard against farmer seed dependence, while retaining the no-GMO transfer benefits promised by terminator seeds. 